\title{
RECENT DEVELOPMENTS IN EXPROPRIATION CLAUSES OF ASIAN INVESTMENT TREATIES
}

\section{Paul Peters*}

1. Introduction

page 46

2. Paradigms

3. Terminology 51

4. The negative formula 55

5. Conditions attached to the right to expropriate 56

5.1. Compensation $\quad 56$

5.2. Public purpose $\quad 59$

5.3. Non-discrimination 60

5.4. Due process of law 62

5.5. Specific undertakings 64

5.6. Catch-all 66

5.7. Clarity 66

5.8. Fair and equitable treatment 67

6. The territorial scope of expropriation 67

7. The object of the expropriation 69

8. Compensation 70

8.1. The Hull formula 71

8.2. Standards of compensation \& valuation $\quad 74$

8.3. The relevant point of time for valuation 77

8.4. Fine-tuning of valuation procedures $\quad 80$

8.5. The time constraint 85

8.6. Payment of interest 86

8.7. Effectiveness $\quad 89$

9. Protection of shareholders $\quad 92$

10. Dispute settlement \& due process of law 94

11. Concluding Remarks 97

$\begin{array}{ll}\text { List of literature } & 102\end{array}$

APPENDIX: Bilateral investment treaties concluded or ratified by countries in South, East and South-East Asia since 1 January 1990

\footnotetext{
* Former legal adviser of companies of the Royal Dutch/Shell Group.

Asian Yearbook of International Law, Volume 5 (Ko Swan Sik et al., eds.; 90-411-0375-9

(c) 1997 Kluwer Law International; printed in the Netherlands), pp. 45-109
} 


\section{INTRODUCTION}

For several decades I have followed developments in the international law on investment, in particular the explosive growth of bilateral investment treaties (BITs hereafter) since the 1960s. Some twenty years ago I started collecting these treaties, as other people collect postage stamps. My collection has grown to almost eight hundred items.

A comparative study of such treaty materials is interesting from several points of view. In the early days these treaties represented the views of a small number of industrialized countries - in particular Germany, Switzerland and the Netherlands - which persuaded some Asian and African developing countries to promote foreign investment by protecting it on the basis of what was then understood to be the minimum international law standard.

A comparative study of BITs shows how views have changed over time, no doubt influenced by the Third World's doctrines laid down in the 1974 Charter of Economic Rights and Duties of States (CERDS), and by the growing realization in many developing and socialist countries during the 1980s and 1990s that a liberal regime based on market principles and international dispute settlement machinery is a better way to promote investment than the rules of CERDS. This change in views and policies of so many developing countries is perhaps most convincingly exemplified by the large number of reciprocal BITs concluded among developing countries inter se. ${ }^{1}$

The worldwide network of BITs is also interesting from other points of view. ${ }^{2}$ It allows an in-depth comparative legal study of subjects dealt with in virtually all BITs, viz. expropriation; the right to transfer capital, profits and other moneys; and dispute settlement. In this paper I shall restrict myself to

\footnotetext{
1 See SORNARAJAH (1994) $234 \mathrm{n}$. 27. He calls into question the reciprocity of BITs such as that between Singapore and Sri Lanka and believes that such BITs are just as much treaties between a capital exporter and a capital importer as are those between an OECD member State and a developing country. The present author does not accept SORNARAJAH's argument; a close study of BITs concluded between developing countries inter se shows that many of them can work both ways. It may be true that the BITs which China (PRC) has entered into with some 70 countries since 1962 first and foremost protect foreign investments in China, but they also protect a large number of small Chinese investments (e.g. restaurants) in the rest of the world. It is interesting to note that virtually all BITs are reciprocal in form and substance, even though sometimes this may be seen as a somewhat hypocritical feature. Exceptions of earlier days are the unilateral BITs between France and Haiti (1973), Indonesia (1973) and Yugoslavia (1974).

${ }^{2}$ See PeTERS (1991) 92, where I mentioned discovery of trends in state practice and treatymaking techniques. Another aspect which will be considered below is the bargaining strength of different countries on any particular issue, e.g. on the HULL formula (see section 8.1 below). Comparison of negotiating results may also bring inconsistent behaviour to light.
} 
one subject only, namely the way BITs deal with expropriation. ${ }^{3}$ I shall analyze for this purpose sixty-two recent Asian ${ }^{4}$ BITs. ${ }^{5}$

The choice of seventeen South, East and South-East Asian countries for this analysis may seem somewhat arbitrary. However, this is the part of the world with the highest rate of economic growth and this growth is in part due to sustained foreign investments. There is no doubt about the importance of foreign investment for economic growth in most of the countries under consideration, ${ }^{6}$ but it is far from clear to what extent BITs have contributed to these investments. ${ }^{7}$ Even though it is impossible to establish a correlation between volume of investments and BIT activities of the country concerned, there is a logical connection: BITs improve confidence and security of potential investors; investment plans are sometimes cancelled because of political risks which could have been reduced by a BIT. ${ }^{8}$

The countries whose recent BITs will be analyzed include those which in recent years have been most successful in terms of economic growth. Some of them have become known as Newly Industrialized Countries (NICs) or Asian tigers. The highest-growth countries in the world, according to 1995 expectations, were (with in brackets the expected 1995 GDP growth rate):

\footnotetext{
${ }^{3}$ In PETERS (1991) 91-161 a similar analysis was made of arbitration clauses found in some 170 BITs and multilateral investment treaties (MITs).

${ }^{4}$ I note that Ko SWAN SIK in 2 AsYIL (1992) at p. 183 has defined Asia for his purposes as excluding "states broadly west of Iran, north of Mongolia and east of Papua New Guinea and south of Indonesia". I have been even more restrictive for the purpose of this paper, by concentrating on seventeen countries in the south, east and south-east of the Asian continent: Bangladesh, China, Hong Kong, Indonesia, Japan, Korea, Laos, Malaysia, Mongolia, Nepal, Pakistan, Papua New Guinea, Philippines, Singapore, Sri Lanka, Thailand and Vietnam.

${ }^{5}$ The sixty-two BITs are identified in the Appendix.

${ }^{6} \mathrm{Japan}$ is an obvious exception. It has experienced several decades of sustained economic growth which cannot be attributed to foreign investments. Although its growth rate has dropped recently to very modest proportions, it remains the dominant economy of the area and is now itself a major source of foreign investment, increasingly in countries of East and South-East Asia.

${ }^{7}$ SORNARAJAH (1994) at pp. 226, 228 and 236 recognizes that writers are divided as to the effect of BITs but emphasizes that it cannot be verified whether a country receives more investments if it concludes BITs. He points out that countries which had not entered into BITs had nevertheless been recipients of investments. DoLZER and STEVENS (1995) at p. 12 present a more positive view and conclude that the legal framework "will no doubt play a role in the decision of any would-be investor".

${ }^{8}$ The author knows from his own experience two cases where plans for major investments in the oil industry were cancelled on grounds of political risks which could not be insured against in the absence of the protection afforded by a BIT between the countries concerned.
} 
China (10\%), Thailand (8.9\%), South Korea (8.5\%), Singapore (8.5\%), Malaysia (8.5\%), Hong Kong (5.8\%). ${ }^{9}$

Virtually all countries in the world want economic growth, developing countries most of all, even though we have all known since the early 1970s that the environment and logic impose limits to everlasting growth of production and consumption. The UN Framework Convention on Climate Change was adopted in 1992 and subsequently ratified by most industrialized and many developing states. Its purpose is to stabilize the concentration of carbon dioxide and other greenhouse gases in the atmosphere at a safe level so as to reduce the dangers of climate change. Unfortunately, growth means an increase of the emission of greenhouse gases and no government so far appears to be ready to sacrifice growth to climate. As and when economic growth will cease to be the overriding priority of states, the pursuit of investments will be reduced (but not necessarily that of BITs, as competition between states for scarce investments will grow). In this author's view that should happen as soon as possible, in the interest of both our common environment and of future generations. It seems fitting to add this comment in a paper devoted to BITs and investment! ${ }^{10}$

For the reasons given above, a study based on treaty practices of Asian countries may not be so arbitrary as appears at first sight. ${ }^{11}$

\section{PARADIGMS}

The following four paradigms represent different approaches. Between them they contain most of the formulas and details which will be discussed in this paper.

\footnotetext{
${ }^{9}$ OECD forecasts of growth of gross domestic product as reported in The Economist of 24 June 1995. Taiwan, with $6.2 \%$, has been omitted because it has no BITs and is therefore not included in our analysis.

${ }^{10}$ See Peters (1995) 366-70; see also MeAdows et al. (1972) and (1991) and DALY (1991).

${ }^{11}$ There is another motivation for the author, who was born in Indonesia (when still a Dutch colony) and who has always been fascinated by cultural aspects of his country of birth.
} 
(a) The 1967 draft Convention of the $\mathrm{OECD}^{12}$ on the protection of foreign property, provided in Article 3:

"No Party shall take any measures depriving, directly or indirectly, of his property a national of another Party unless the following conditions are complied with:

(i) The measures are taken in the public interest and under due process of law;

(ii) The measures are not discriminatory; and

(iii) The measures are accompanied by provision for the payment of just compensation. Such compensation shall represent the genuine value of the property affected, shall be paid without undue delay, and shall be transferable to the extent necessary to make it effective for the national entitled thereto."

(b) The BIT between Australia and Papua New Guinea (1990), Article 7:

“(1) Neither Contracting Party shall take any measures of expropriation, nationalisation or any other dispossession having effect equivalent to nationalisation or expropriation against the investments of nationals or companies of the other Contracting Party, except under the following conditions:

(a) the measures are taken for a public purpose and under due process of law;

(b) the measures are non-discriminatory; and

(c) the measures are accompanied by provisions ${ }^{13}$ for the payment of prompt, adequate and effective compensation.

(2) The compensation referred to in paragraph 1 of this Article shall be computed on the basis of the market value of the investment as a going concern immediately before the measures become public knowledge. Where that value cannot be readily ascertained, the compensation shall be determined

\footnotetext{
${ }^{12}$ The draft Convention (hereafter referred to as 'the OECD Convention') was unanimously approved in 1967 by the OECD Council, Turkey abstaining, but has never been ratified. It has influenced many of the BITs which were subsequently concluded. It is also known as the AbsShawcross Convention after the two men who were instrumental in drawing up this instrument, the German banker ABS and the former British Labour minister Sir (later: Lord) HARTLEY SHAWCROSS.

${ }^{13}$ The plural form of the word 'provision' is curious. This clause closely follows the wording of the OECD Convention where 'provision' is used in the singular, which means that at the time of the expropriation provision must have been made, i.e. the necessary funds must have been earmarked for compensation (but need not yet have been paid out); it is a budgetary act. The requirement of accompanying 'provisions' can only mean that the state must lay down in writing the procedure of payment, without necessarily guaranteeing it. See section 8.5 below.
} 
in accordance with generally recognised principles of valuation and equitable principles taking into account the capital invested, depreciation, capital already repatriated, replacement value and other relevant factors.

(3) The compensation shall be paid without undue delay, shall include interest at a commercially reasonable rate from the date the measures were taken to the date of payment and shall be freely transferable between the territories of the Contracting Parties. The compensation shall be payable either in the currency in which the investment or investments were originally made or, if requested by the national or company, in a freely convertible currency."

(c) Indonesia-Korea (1991), in Article 6:

“(1) Investments of investors of either party shall not be nationalized, expropriated or subjected to measures having effect equivalent to nationalization or expropriation (hereinafter referred to as 'expropriation') in the territory of the other party except for a public purpose related to the internal needs of the expropriating party and against full, prompt and effective compensation. ${ }^{14}$ Such compensation, including interest from the date of expropriation, ${ }^{15}$ shall amount to the market value of the investment expropriated prior to the moment in which the decision to expropriate is announced or made public. Compensation shall be made without undue delay, effectively realizable and freely transferable. The legality of any expropriation and its procedures, the amount and the method of payment of compensation shall be subject to review by due process of law in accordance with the existing ${ }^{16}$ laws and regulations of the expropriating party.

(2) Where a party expropriates the assets of a company which is incorporated or constituted under the law in force in any part of its territory, and in which nationals or companies of the other party own shares, it shall insure that the provisions of paragraph (1) of this Article are applied to the extent necessary

\footnotetext{
${ }^{14}$ It is interesting to compare this with the corresponding clause in the BIT between Indonesia and Norway, which simply requires 'compensation', without using the HULL formula; and which adds the condition of non-discrimination.

${ }^{15}$ This language is confusing. What it appears to say is that the sum of compensation proper and interest must amount to the market value; the intention is no doubt that the amount of compensation must be equal to the market value and that on top of that interest must be paid.

${ }^{16}$ What is the meaning of the word 'existing'? It could mean: existing at the time when the investment agreement was made or when the investment was started (or even: existing at the date when this BIT was signed). This would be a stabilizing clause, protecting the investor against changes in the law subsequently made with the purpose of diminishing his right to compensation or protection. But 'existing' can also be interpreted as existing from time to time, in which case this due-process clause affords little protection. On stabilization clauses see SORNARAJAH (1994) 328.
} 
to guarantee compensation provided for in that paragraph to the owners of those shares."

(d) China-Pakistan (1989), Article 4:

“1. Either Contracting Party may, for the security and public interest, expropriate, nationalize or take similar measures (hereinafter referred to as 'expropriatory measures') against investment assets of investors of the other Contracting Party in its territory, but the following conditions shall be complied with:

a) under domestic legal procedure of the Contracting Party taking expropriatory measures;

b) being non-discriminatory;

c) being against compensation.

2. The compensation mentioned in Paragraph 1, (c) of this Article shall be in accordance with the laws and regulations of the Contracting Party taking expropriatory measures in convertible currencies. The compensation shall be paid without unreasonable delay.

3. If an investor considers the expropriation mentioned in Paragraph 1 of this Article incompatible with the laws of the Contracting Party taking the expropriatory measures, the competent court of the Contracting Party taking the expropriatory measures may, upon the request of the investor, review the said expropriation."

\section{TERMINOLOGY}

Most BITs refer to 'expropriation' and 'nationalization' and include 'creeping expropriation' one way or another. Many BITs then designate one term, usually expropriation, for further reference, to cover all the various measures that may be taken (see paradigms (c) and (d) in section 2 above). In this paper, too, unless otherwise indicated, the expression expropriation will be used to cover all forms of direct and indirect measures under discussion. ${ }^{17}$

It is remarkable that not a single BIT makes an attempt to define or distinguish the terms used. The question of the definition of terms such as expropriation and nationalization is a controversial matter in the literature. Usually 'expropriation' is used as the generic term covering all measures taken by a government whereby companies or individuals may, for the common good, be

\footnotetext{
${ }^{17}$ Another generic term often used in the literature, and sometimes in BITs, is 'taking'.
} 
deprived of property or of certain types of rights, ${ }^{18}$ subject to some exceptions such as taxation; while 'nationalization' is used for those cases of expropriation whereby a whole industry is brought under government control. ${ }^{19}$

The terms used in our sample of sixty-two BITs are: 'expropriation' (55x), 'nationalization' (53x), 'dispossession' (5x), 'deprivation of investment' (8x), 'seizure' (1x), 'State intervention' (1x) and 'requisitioning' $(2 \mathrm{x})$. These terms are meant to cover the straightforward measures. There are several ways in which the Contracting Parties attempt to catch also cases of so-called 'creeping nationalization', i.e. all those cases which are not straightforward. ${ }^{21}$

Three BITs ${ }^{22}$ include a formula of Italian origin with a wider description of governmental measures which are forbidden, viz. measures which "might ${ }^{23}$ limit permanently or temporarily their [i.e. the investors'] rights of ownership, possession, control or enjoyment, save where specifically provided by law and by judgments or orders issued by Courts or Tribunals having jurisdiction" ${ }^{24}$ The saving clause at the end is obviously meant to limit the scope of the prohibition by excluding 'legitimate' measures for which no compensation should be due, such as the levying of normal taxes and court orders based on company law, ${ }^{25}$ but throws away the baby with the bath water, for most cases of expropriation, whether or not legitimate, would also fall under this saving clause. To define in clear terms when (expropriatory) measures are legitimate and when they are not, when they should give rise to compensation, and when they should not, is obviously difficult.

A clause of German origin reads: "A claim to compensation shall also exist when, as a result of State intervention in the company in which the investment is made, its economic substance is severely impaired". ${ }^{26}$

\footnotetext{
${ }^{18}$ The rights in question include long-term rights of a contractual nature and concessions or industrial licences granted by the government.

${ }^{19}$ Cf. SCHRIJVER (1995) 270.

${ }^{20} \mathrm{Japan}$-Turkey uses this term in the valuation clause, stipulating that no reduction in value may be taken into account which is "due to the prospect of the very seizure which ultimately occurs" (Art. 5.3). The English text is the only authentic text of this treaty.

${ }^{21}$ See the American Law Institute's 1987 Restatement on the Foreign Relations Law of the United States (Third), Vol. 2 p. 200. See also n. 34 below.

${ }^{22}$ The Italian BITs with Vietnam, Mongolia and Bangladesh.

${ }^{23}$ The potential mood of the word 'might' is confusing. The French language version of this clause, used in the Vietnam-Italy BIT, refers simply to "une mesure . . . qui limite le droit de propriété ...".

${ }^{24}$ BIT Mongolia-Italy, Art. 5.

${ }^{25}$ An example is the well-known Fruehauf case where the superior court in Paris removed the American managing director of the French Fruehauf subsidiary and replaced him by a government-appointed administrator. See 5 ILM (1966) 476.

${ }^{26}$ The German BITs with Mongolia and Vietnam.
} 
The most common formulas used for creeping nationalization are: "measures with equivalent effect", ${ }^{27}$ i.e. effect equivalent to that of straightforward expropriation (31x) or "with similar effect" (14x); "measures tantamount to expropriation" or "measures having effects tantamount to expropriation" (4x); "directly or indirectly", e.g. investments shall not be expropriated directly or indirectly $(15 \mathrm{x})$.

Terminology as such is not of much interest. What is important for our analysis is the definition of the terms used, so that it is clear when government measures are subject to conditions with regard to compensation (or give rise to a right to compensation ${ }^{28}$ and when they are not; and also what government measures are subject to the test of public purpose, non-discrimination etc. The terminology used in BITs and the failure to define terms may create problems of interpretation which in due course will no doubt be resolved by arbitration. There is a wide range of government measures which interfere with operations of investors and may have effects similar to those of expropriation, but which are non-compensable; such measures are generally considered to be legitimate government regulation of business. ${ }^{29}$ The exercise of taxation powers is but one obvious example. Even though so far this lack of clarity in the language used in BITs has not created major problems, legal security of investors would be enhanced by greater precision.

The use of a single term, e.g. expropriation, to make it possible later to refer back to the whole range of measures covered by a variety of terms, is of course merely a drafting device which hardly deserves our attention. Except for one thing: without such a catch-all expression it is easy to create confusion or to leave gaps in the protection of investors, gaps which the parties in drawing up the BIT clearly had not intended. For instance, when the opening phrase provides that investments shall not be subjected to expropriation or to other measures with equivalent effect (unless certain conditions are fulfilled) and a later clause provides for interest to be paid over the period between expropriation and payment of compensation, the question arises whether interest is due in case of a measure which is not expropriation but which does have equivalent effects. An arbitral tribunal would be unlikely to deny payment

\footnotetext{
${ }^{27}$ Emphasis added in quotations in this article does not appear in the original text unless otherwise indicated.

${ }^{28}$ The distinction between compensation as a condition precedent and compensation as a subsequent obligation is discussed in section 4 below.

${ }^{29}$ See SornARAJAH (1994) 283; Dolzer and STEVENS (1995) 98 et seq.
} 
of interest if the opening phrase had included at the end the words "(hereinafter referred to as expropriation)"..$^{30}$

Finally on this subject let us review the language used in three sources which have been important for the development of BITs: the OECD Convention, ${ }^{31}$ the 1984 AALCC model BITs ${ }^{32}$ and the World Bank Group's Guidelines of $1992^{33}$ on the treatment of foreign direct investment.

Article 3 of the OECD instrument prescribes that the host country shall not take any measures depriving the investor, directly or indirectly, of his property ${ }^{34}$ unless certain conditions are complied with.

The AALCC text provides in Article 7 of Model $\mathrm{A}^{35}$ and in alternative 2 of Article 7 of Model B that investments shall not be nationalized, expropriated or subjected to measures having effect equivalent to nationalization or expropriation except . . .; and in alternative 1 of Article 7 of Model B that the host country may exercise its sovereign rights in the matter of nationalization or expropriation in respect of investments upon payment of . . ., subject to .....36

The World Bank Guidelines provide in paragraph 4 that the state may not expropriate or otherwise take in whole or in part an investment, or take measures which have similar effects, except ....

\footnotetext{
${ }^{30} \mathrm{Cf}$. China-Argentina which, as a result of such a drafting error, denies arbitration in case of creeping expropriation. See also section 8.6 below at $n$. 116 .

${ }^{31}$ See n. 12 above.

${ }^{32}$ The model BITs drawn up by the Asian-African Legal Consultative Committee, see 23 ILM (1984) 237.

${ }^{33}$ See the 1992 Report to the Development Committee of the Board of Governors of the IMF and the World Bank, containing Guidelines on the treatment of foreign direct investment. In September 1992 the Development Committee drew the Guidelines to the attention of member countries. Hereafter referred to as World Bank Guidelines.

${ }^{34}$ According to the notes to Article 3 the word 'property' is used in its widest sense and includes contractual rights. These notes also contain an interesting exposition on indirect deprivation, i.e. creeping nationalization. It covers wrongful government interference with the use of property over a long period. "Under it, measures otherwise lawful are applied in such a way as to deprive ultimately the alien of the enjoyment or value of his property, without any specific act being identifiable as outright deprivation. As instances may be quoted excessive or arbitrary taxation; prohibition of dividend distribution coupled with compulsory loans; imposition of administrators; prohibition or dismissal of staff; refusal of access to raw materials or of essential export or import licences".

${ }^{35}$ We shall leave Model C out of account in this paper because it is identical to Model $\mathrm{A}$ in all relevant aspects.

${ }^{36}$ In its introduction the AALCC explains that Model A represents a more liberal standard, while Model B contains provisions which are somewhat more restrictive (read: more inspired by CERDS). On expropriation the restrictionists appear to have been split; only alternative 1 reflects the CERDS philosophy. See 23 ILM (1984) 237.
} 


\section{THE NEGATIVE FORMULA}

In the ideological battles fought in the General Assembly of the UN between the group of developing countries, the so-called G 77, and a number of industrialized countries, around resolutions adopted in 1974 concerning a New International Economic Order (NIEO) and the Charter of Economic Rights and Duties of States (CERDS), spokesmen for G 77 insisted on the unconditional right of the State to expropriate, while the capital exporters did not want to go beyond recognition of a conditional right of expropriation. The former therefore preferred a positive clause on expropriation such as formulated in the fourth paradigm set out in section 2 under (d) above and in the text of Model B, alternative 1 of the AALCC represented at the end of section 3 above, rather than the negative formula included in the AALCC's Model A text, as well as in the OECD and World Bank provisions and the other paradigms of section 2. In our sample of sixty-two BITs there are some which follow the positive line: the host country may expropriate but the following conditions on compensation and other matters must be complied with (obligations ex post or 'conditions subsequent') ${ }^{37}$ The great majority (fiftyeight BITs), however, stick to the traditional negative formula whereby expropriation is forbidden except where certain conditions precedent have been fulfilled. The distinction appears to be an exercise in doctrinal hairsplitting and of little practical interest. Nevertheless it may have consequences for the question whether or not an expropriation is lawful, a question which could have a significant effect on the amount of compensation due by the expropriating state. ${ }^{38}$

All BITs, without exception, attach conditions to the state's right to expropriate. It stands to reason that supporters of the positive line, emphasising the absolute nature of the state's right, will use conditions subsequent, while

\footnotetext{
${ }^{37}$ China-Pakistan and China-Philippines. China-Pakistan provides that the state may expropriate investments "but the following conditions shall be complied with: ...". Another example is the Morocco-Portugal BIT of 1988 which uses a positive formula and clearly qualifies compensation as a condition subsequent, by providing that "les mesures ... d'expropriation ... qui pourraient être prises par les autorités de l'une des Parties contractantes à l'encontre des investissements appertenant à des ressortissants ou sociétés de l'autre Partie contractante devront être conformes aux prescriptions légales, et ne devront être ni discriminatoires ni motivées par des raisons autre que l'utilité publique. La Partie contractante ayant pris de telles mesures versera à l'ayant-droit, une indemnité juste et équitable" (Art. 6).

${ }^{38}$ See SORNARAJAH (1994) 321.
} 
adherents of a liberal policy formulate them as conditions precedent. However, in practice most BITs contain a mixed system. ${ }^{39}$

\section{CONDITIONS ATTACHED TO THE RIGHT TO EXPROPRIATE}

Most BITs list three or four conditions, usually as conditions precedent. But some list only two,${ }^{40}$ whereas some others go to five or even six. ${ }^{41}$ The following eight conditions occur in our sample, in order of frequency:

\subsection{Compensation}

Compensation is universally accepted in all BITs. The phraseology differs in ways indicating political, indeed ideological, sensitivities surrounding the subject, but there can be no doubt that it is the most important of all the conditions, both in the eyes of the expropriating states and home countries for some of which it has become a matter of ideological importance - and for the investors for whom compensation in case of expropriation is an economic imperative.$^{42}$ Notwithstanding its importance, compensation usually is the last item in the list of conditions set out in the expropriation article. ${ }^{43}$

\footnotetext{
${ }^{39}$ Alternative 1 of the AALCC's Model B text resorts to a mixture of conditions subsequent and precedent. It says: upon payment of appropriate compensation the state may expropriate, subject to the provisions of its laws (two conditions precedent: on compensation and on due process of law) and then goes on with the following condition subsequent: the host state shall abide by and honour any commitments made or assurances given both in regard to nationalization or expropriation and the principles for determination of appropriate compensation ...

Indonesia-Netherlands has 4 conditions precedent and one condition subsequent; the French treaties with Vietnam and Mongolia have 3 and 1, respectively; China-Korea, Korea-Turkey and the Thai treaties with Czechoslovakia and Peru have 2 of each; the Korean treaties with USSR and Mongolia have 1 and 3, respectively.

${ }^{40}$ The Korean BITs with Thailand and Indonesia; the German BITs with Vietnam and Mongolia; Indonesia-Italy; and Nepal-UK all depend on two conditions only: public purpose and compensation.

${ }^{41}$ Mongolia-US lists them all (six).

${ }^{42}$ The economic consequences of compensation also affect host and home countries of course. Poor host countries often lack the means to pay full compensation promptly. Home countries often insure 'political risks' of their investors, so that in the end it may be the home state rather than the enterprise which has to foot the bill; and even when there is no such insurance, large losses incurred by their nationals on foreign investments will reflect on home states' prosperity.

${ }^{43}$ In 7 BITs, however, compensation takes the second place in a list of four. In 4 BITs it takes the third place in a list of 4-6 conditions.
} 
The 'classical' formula for the minimum standard of international law for compensation in case of expropriation is "prompt, adequate and effective compensation", the words used by the American Secretary of State CORDELL HULL in 1938 when he wrote to the Mexican ambassador after the nationalization of American oil interests in Mexico. This so-called triple formula received wide adherence from many industrialized countries during the 1940s and 50s and still today is regarded by a number of countries as the true minimum standard of international law. ${ }^{44}$ Its significance does not lie in the words used which, without further definition, carry little meaning ${ }^{45}$ but rather serve as a battle cry to uphold the old values of the classical rules of international economic law such as it was developed by the major industrialized countries during the first half of this century against the nationalization policies of the USSR and Mexico. It was a major bone of contention between developed and developing countries for several decades, say between 1950 and 1980. The battle cry on the other side, the developing countries, is - or was - 'appropriate' compensation, ${ }^{46}$ a term as meaningless as 'adequate'. It seems to this author that the controversy around the qualifiers 'adequate', 'appropriate' and some others such as 'fair' and 'reasonable' is about prestige and about the strife between North and South, between capitalism and socialism. It has little to do with the standard of compensation.

The basic point is that the obligation to pay compensation is now generally accepted. ${ }^{47}$ Details of time, amount and numerous other particulars remain controversial and there are significant differences between BITs. We shall discuss these below.

It is interesting to observe that the 1967 OECD Convention does not contain the HULL formula, which even then was controversial, but instead requires that expropriation measures "are accompanied by provision for the payment of just compensation". The word accompanied is significant. It means that provision for payment and expropriation must be simultaneous. The word

\footnotetext{
${ }^{44}$ Countries adhering to the HULL formula whenever it is possible to do so include the US, UK, Australia, Canada, Denmark, Finland and Sweden. See section 8.1 below.

45 'Prompt' seldom means immediately and is occasionally defined as meaning without undue delay or as within 2 months. 'Adequate' does not provide any useful guidance as to the standard of compensation (it could be interpreted as less than 'full' compensation, although that is not the intention). 'Effective' again is meaningless unless the term is defined. We shall revert to the HULL formula in section 8.1 below.

${ }^{46}$ Art. 2.2 of CERDS lays down that "appropriate compensation should be paid by the State adopting such measures" (i.e. nationalization, expropriation or transfer of ownership of foreign property).

${ }^{47}$ That was certainly not the case in 1974 when Art. 2 of CERDS was adopted in the General Assembly of the UN.
} 
provision is also significant. It means that the expropriating state must have taken all necessary administrative measures to ensure that compensation will be paid as indicated in the treaty, including the creation of a budgetary reserve for the amount to be paid. ${ }^{48}$

The AALCC text, surprisingly, adopts the HULL formula in Model A, while the NIEO-oriented Model B allows expropriation only "upon payment of appropriate compensation" adding, however, that this is subject to the provisions of the host country laws (alternative 1$)^{49}$ or "against prompt payment of appropriate compensation" (alternative 2).

The World Bank Guidelines require "payment of appropriate compensation" as well, adding a rider that compensation will be deemed appropriate if it is "adequate, effective and prompt" and then go on to define 'adequate' in considerable detail. It is an interesting exercise in running with the HULL hare while hunting with the CERDS hounds!

The HULL formula has regained popularity during the last ten years. It appears in twenty-three out of the sixty-two BITs analyzed; a further seven clauses use wording which is almost the same as the HULL formula. On the other hand, twenty-five BITs merely require, by way of condition precedent, compensation, without any qualification. In most of these treaties, however, a further clause on valuation is given. See further section 8 below.

\footnotetext{
${ }^{48}$ Some BITs (Vietnam-Germany, Vietnam-Sweden) have taken over this formula calling for "provision for payment" accompanying the measure, but in some cases (China-Greece, Papua New Guinea-Australia) the plural "provisions" is used, and that changes the meaning, probably unintentionally. Cf. $\mathrm{n} .13$ above and section 8.5 below.

${ }^{49}$ This text is ambiguous as it is unclear whether the reference to the host country's laws only qualifies payment of compensation, or also the right to expropriate.
} 


\subsection{Public purpose}

Public purpose or equivalent (e.g. public interest, social interest, public utility) comes next in frequency. The OECD Convention requires that "the measures are taken in the public interest"; the AALCC gives a choice between "for a public purpose" and "in the national interest", except in the restrictive alternative 1 of Model B which, for reasons which are unclear, leaves out this criterion altogether. The World Bank Guidelines require that the measures are taken "in pursuance in good faith of a public purpose". Thirty-eight of the sixty-two BITs in our sample refer to a public purpose, seventeen of these to a "public purpose related to the internal needs of the expropriating country", twenty-six to public interest, three to social interests, and four to public security.

The predilection of some countries for a public purpose related to the state's internal needs is difficult to understand. It seems a tautology as it is hard to visualize a case where the public purpose for which recourse is had to expropriation would have no relationship to the internal needs of the state. The expression was first used by the UK in BITs with Singapore (1975), Egypt and Korea (both 1976), Indonesia (1977) and China (1986). ${ }^{50}$ Most of the later BITs concluded by the UK include this curious reference to 'internal needs'. A possible explanation for the introduction of this phrase in 1975 may lie in the nationalization of the Suez Canal in 1956. The drafters of the phrase may have thought - incorrectly in my view - that the nationalization of an international waterway, while serving a public purpose, had nothing to do with the internal needs of Egypt. This phraseology was later adopted by Australia and Hong Kong in most of their BITs (but not by Canada and New Zealand), and by Denmark and Indonesia. It was resisted by a number of countries, ${ }^{51}$ as becomes clear when BITs are compared in detail.

\footnotetext{
${ }^{50}$ But not in UK-Romania (1976) and UK-Thailand (1979). Presumably Romania and Thailand objected to the expression, either because they considered it meaningless or, if not meaningless, because it would put an additional restriction on the right to expropriate.

${ }^{51}$ The objectors include Papua New Guinea (see its BIT with Australia of 1990); China, which has resisted the clause in all its BITs; Russia (see its BIT with Denmark of 1989); Norway (BIT with Indonesia of 1991). Clearly there are three groups of countries: those who want the clause (UK, Australia, Hong Kong, Denmark, Indonesia); those who resist it and those who are indifferent. Some of the objectors have been inconsistent: the Philippines rejected the clause in its BIT with the UK (1980), but accepted it in the BIT with Australia (1995); similarly Thailand said no to the UK in 1978 but yes to Korea in 1989; on the other hand Papua New Guinea first accepted it in 1981 from the UK but later rejected it in the BIT with Australia (1990). The motivation of the objectors is unknown, but see $\mathrm{n}$. 50 for a possible reason. See also DoLzER and STEVENS (1995) 105 at n. 287, and the text below at $n .55$.
} 
Several BITs expand on the customary words 'public purpose' in more detail. For instance, Japan-Turkey specifies that the term public purpose includes the purposes of national defence. Philippines-Spain explains that the measures must have been taken "por causas de utilidad pública o de interés público, incluidas las que tengan fines asistenciales o defensivos", thereby bringing both social security and defence specifically within the orbit of "public purposes'.

The condition that the taking must be for a public purpose (or a similar expression) is included in all sixty-two BITs, in all but seven in first place. Clearly, states attach importance to it. ${ }^{52}$ And yet it is recognized by most writers that this condition has little practical significance, as a court or arbitral tribunal is unlikely to be able to come to the conclusion that expropriating measures lack a public purpose if the sovereign state which took those measures insists that they served a public purpose. ${ }^{53}$

This condition is almost always formulated as a condition precedent, and rightly so, because the public purpose logically must precede the act of expropriation which purports to be legitimized by it. This logic is less obvious in the other so-called conditions precedent. In the case of payment of compensation the formula sometimes suggests: first pay, then expropriate. But it never happens in this sequence and it would not be realistic to insist on prepayment. The best an investor may hope for is prompt payment after the act. And it is the same with other conditions which are usually formulated as conditions precedent (absence of discrimination, due process of law, no conflict with previous undertakings): these conditions logically cannot be fulfilled prior to the act of expropriation.

\subsection{Non-discrimination}

Non-discrimination is the third condition for a lawful expropriation and is included in most BITs. The OECD Convention requires that "the measures are not discriminatory". The AALCC Model A contains a proviso to the effect that the measures must have been taken "on a non-discriminatory basis", but the more restrictive Model B leaves out any mention of non-discrimination in both its alternative texts. The World Bank Guidelines require that the expropriation

\footnotetext{
${ }^{52}$ It is therefore difficult to understand why it is omitted in the AALCC Model B clause (see above).

${ }^{53}$ See Sornarajah (1994) 316; Dolzer and SteVens (1995) 104; and Schruver (1995) 276, 329-330. SORNARAJAH errs where he says in his n. 95 on p. 316 that the OECD (ABSSHAWCROSS) Convention left out the public purpose requirement.
} 
is done "without discrimination on the basis of nationality". And yet ten of the sixty-two BITs omit the non-discrimination criterion. ${ }^{54}$ Historically this criterion has played an important role. When in 1971 Libya nationalized British Petroleum's concessions, it did so clearly for political reasons, as retaliation against the UK because it had, according to Libya, harmed Arab interests by failing to prevent the occupation by Iran of three small islands in the Persian Gulf which had been under British protection. Statements by the Libyan president and other authorities acknowledged that the nationalization was retaliatory and an expression of Arab anger. The UK government's note of protest said, inter alia, that "nationalisation measures which are arbitrary or discriminatory or which are motivated by considerations of a political nature unrelated to the internal well-being of the taking State are ... illegal and invalid" ${ }^{55}$ Similarly discriminatory expropriations of British oil interests have taken place later, for instance in $\mathrm{Iraq}^{56}$ and Nigeria. Earlier, Netherlands interests had been nationalized in Indonesia as retaliation for the refusal of the Netherlands government to transfer sovereignty over Dutch New Guinea (Irian Jaya) to Indonesia. It is not surprising therefore that the UK and the Netherlands insist, whenever possible, on the non-discrimination requirement. France, the Scandinavian countries, US and Poland also have a clear-cut predilection for this clause. A review of French, US and Dutch BITs reveals that such a requirement is included without exception, even in BITs with countries which are normally reluctant or even unwilling to include it. Surprisingly, some of the UK BITs have omitted the non-discrimination requirement, for instance

\footnotetext{
${ }^{54}$ Four of the ten Korean BITs (those with Thailand, Indonesia, Austria and Poland); another two Thai BITs (those with Czechoslovakia and Peru); another Indonesian BIT (with Italy); the German BITs with Mongolia and Vietnam; and Nepal-UK. It would appear, also taking into account other BITs of the countries concerned, that the main objectors (or abstainers) are Austria, Germany, Indonesia and Thailand. Hong Kong leaves out non-discrimination from its model BIT as published in DOLZER and STEVENS (1995) at 200, but nevertheless included it in all five BITs analyzed for this study.

55 See R.B. von MEHREN and P.N. Kourides, 'The Libyan Nationalization Cases', in 75 AJIL (1981) 486.

${ }^{56}$ The Iraqi case is interesting, in that concession rights of the Iraq Petroleum Co. (IPC) were partly nationalized in 1972 for a curious reason. The Royal Dutch/Shell Group owned $23.75 \%$ of IPC. As the British parent company of Royal Dutch/Shell owned $40 \%$ of the Group (the other $60 \%$ being owned by Royal Dutch Petroleum Co., a Dutch company) and the Iraqi measure was directed solely against the UK, Iraq decided to expropriate only $40 \%$ of the Group's $23.75 \%$ share in the Iraqi concession rights.
} 
those with China and Nepal, even though most Chinese BITs ${ }^{57}$ include it and so does Nepal-France.

The countries which do not have the requirement in most of their BITs, and which therefore could perhaps be labelled persistent objectors, include Austria, Germany, Indonesia and Thailand. In the case of the first two (industrialized) countries the omission is difficult to understand. Germany, which has more BITs to its credit than any other country ${ }^{58}$ supported the non-discrimination requirement in the OECD Convention of 1967. The reluctance of the two developing countries may be due to doctrines of the Group of 77 with regard to expropriation, which found expression in the UNGA resolutions adopted in 1974 on a New International Economic Order and the Charter of Economic Rights and Duties of States. NIEO and CERDS emphasized the right of states to nationalize foreign investments without restrictions imposed by international law. ${ }^{59}$ It is consistent with this doctrine to reject conditions precedent such as the one on non-discrimination.

\subsection{Due process of law}

The fourth most frequent condition is best known under the name of due process of law, although various other expressions are used. Due process can mean either or both of two different things: the expropriation measures must have been taken in accordance with the law of the expropriating state, and the expropriated investor must have the right ex post facto to test the legality of the measure in an independent court or administrative tribunal of the host country. A number of BITs (Vietnam-Denmark and the Mongolia treaties with Germany, UK, US and Denmark) clearly combine the two meanings by giving investors the right to go to court to review the legality of the expropriation and/or the amount of compensation by due process of law.

The condition that the measure must be in accordance with the (applicable) laws (and regulations) of the host country, or a variation on that theme, is used in eleven of the sixty-two BITs. It requires compliance with all law, both substantive and procedural. A second category is the seemingly less farreaching condition that the measure be taken under (domestic) legal pro-

\footnotetext{
${ }^{57}$ China-UK dates from 1986. Of the seventeen BITs concluded by China in the years up to and including 1986 only six leave out the non-discrimination clause, namely those with the consistent objectors Austria, Germany and Thailand and those with Italy, Romania and Sweden. The omission in China-UK and China-Sweden is therefore difficult to understand.

${ }^{58}$ As of 27 March 1995 Germany had 93 treaties, of which 68 in force.

${ }^{59}$ See in particular Art. 2 of CERDS, n. 79 below.
} 
cedures, formulated in twenty BITs. It refers to procedural law only. In most states it is nowadays probably a matter of course that the state is bound by its own substantive rules of law, as well as by its legal procedures. Finally there are twenty BITs which use the somewhat ambiguous term due process of law.

The OECD Convention contains the condition that the measures are taken under due process of law. The notes explain that the notion of due process is akin to the requirements of the rule of law or those of the 'Rechtsstaat' and that in an international agreement international as well as national law must be taken into account. Due process implies, according to the notes, that the expropriation measures must be free from arbitrariness; constitutional safeguards and those laid down in other laws or in judicial precedent must be observed; administrative or judicial machinery must correspond to the minimum standard of international law; the legality of the measures and wherever the constitutional rules of the state concerned permit it - the amount of compensation should be subject to judicial review. This very wide definition of due process covers both meanings indicated above.

It should be noted that, according to ABS and SHAwCROSS, the authors of the notes, legality and amount "should be subject to judicial review" irrespective of the wishes of the investor or indeed the host country itself. It may well be that they do not want to go to the national court but want to submit any questions that may arise straight to international arbitration. Indeed, there is much to be said in favour of skipping the local means of dispute settlement if in the end the judgment of an arbitral court will prevail in any case. ${ }^{60}$

Model A of the AALCC requires that an expropriation must be "in accordance with its [i.e. the host country's] laws". Model B alternative 1 is ambiguous. it says, in effect, that a state may expropriate upon payment of appropriate compensation, "subject however to the provisions of its laws", but it is unclear what is the antecedent of the words emphasized: compensation only, or also the expropriation itself. ${ }^{61}$ The second Model B alternative is silent on due process.

The World Bank Guidelines provide that expropriation measures must be taken "in accordance with applicable legal procedures". There is no reference here to the law or legal procedures of the expropriating country. The words "applicable legal procedures" are wide enough to encompass international as well as national legal procedures.

${ }^{60}$ See Peters (1991) 134; per contra SoRnARAJAH (1994) 271.

${ }^{61}$ Cf. n. 49 above. 


\subsection{Specific undertakings}

A fifth condition precedent requires that the expropriation measures may not be contrary to a specific undertaking previously given by the state in question. It is a standard condition in French and Dutch BITs. ${ }^{62} \mathrm{~A}$ similar clause exists in the US treaties with Mongolia and Sri Lanka. ${ }^{63}$

A clause which prohibits expropriation when it would be contrary to an undertaking previously given, is a so-called 'stabilization clause', a clause which purports to limit the freedom of the state concerned to take measures it deems necessary. If the state nevertheless expropriates, the expropriation is unlawful. It is a violation of the treaty and therefore a wrongful act for which the home country can claim reparation in the form of restitutio in integrum (unlikely to be awarded in the light of precedents) ${ }^{64}$ or full damages including lucrum cessans.

SORNARAJAH deals at length with clauses of BITs designed to uphold commitments given to investors and with the merits of stabilization clauses in general. ${ }^{65} \mathrm{He}$ expresses considerable doubts with regard to stabilization clauses - described as clauses which seek to freeze the law of the host state,

\footnotetext{
${ }^{62}$ See Vietnam-France, Vietnam-Netherlands, Mongolia-France, Indonesia-Netherlands and Laos-France. This condition was omitted in the French and Dutch BITs with China (1984 and 1985, respectively), from which it is clear that China objected to making the legality of expropriation dependent on compliance with a specific undertaking given with regard to expropriation. China, however, did accept in its BIT with the UK (1986) the standard British clause on the same subject, which forms part of an article on protection of investment, not of the expropriation article, and which reads: "Each Contracting Party shall observe any obligation it may have entered into with regard to investments of nationals of the other Contracting Party" (this same sentence is also included in Vietnam-Netherlands). There is no significant difference between the 'undertaking' in the former clauses ("the measures are not contrary to any undertaking which the Contracting Party which takes such measures may have given"; or "à condition que ces mesures ne soient pas contraires à un engagement particulier") and the 'obligation' in the latter, apart from the fact that the scope of the former clause is restricted to expropriation and the latter is general.

It should be noted that in one respect both clauses are equally ambiguous and open to misinterpretation: it could be argued that the first clause would only apply when a specific undertaking has been given to the other Contracting Party, i.e. the home country, so that undertakings given to the investor would not trigger the clause. And similarly, in the case of the second clause, that it could only be invoked successfully if the obligation had been entered into vis-à-vis the home country (not the investor). Such an interpretation, in my view, is not in accordance with the intentions of the Contracting Parties in the more than hundred BITs in which these clauses appear, and if ever submitted to arbitration is unlikely to be upheld.

${ }^{63}$ See section 5.6 below.

${ }^{64}$ See the award by Sole Arbitrator LAGERGREN in the arbitration between BP and Libya, 53 ILR 351 et seq.

${ }^{65}$ SORNARAJAH (1994) 264-265 and 328-332.
} 
with the intention of immunizing the investment contract from changes in taxation, environmental controls etc. - and concludes that it is unclear to what extent such a provision (in a BIT) will limit sovereign and regulatory powers of the host state. But he goes on to say that unilateral guarantees not to nationalize except on payment of full compensation will be protected by such a provision in a BIT. I would go further: in my view a contractual undertaking made by the host state to the investor, to the effect that the investment will not be expropriated during the first $n$ years, is likely to be upheld by arbitrators, unless they find that the period $n$ is unreasonably long or the investor has violated his obligations under the investment contract to such a degree that he can no longer in good faith invoke the host state's contractual undertaking (in other words, he is estopped from relying on the undertaking).

It is as unusual for an investment contract to lay down the terms on which the state may take over the enterprise as it is for marriage vows to include divorce terms. And yet, spelling out such terms in an investment contract might avoid a lot of trouble and acrimony later. An investor, knowing that the sovereign state has the right (subject to certain conditions) to expropriate his investment, may be wise to forestall unilateral action by negotiating, and including in his contract on what terms, and when, the state may take over the business (i.e. an option in favour of the state, based on liquidated damages). Such a clause also defines up till when the state may not do so. Such an arrangement, in my view, would enhance legal security and would make good business sense in long-term contracts, but only if it is recognized that expropriation may never be contrary to a specific undertaking given by the state.

The OECD Convention does not contain this condition. It does, however, have a general article on observance of undertakings or pacta sunt servanda (Art. 2): "Each Party shall at all times ensure the observance of undertakings given by it in relation to property of nationals of any other Party." The AALCC Models do not have the clause under discussion in their more liberal versions (Model A and alternative 2 of Model B), but surprisingly include a pacta servanda provision in the expropriation clause of alternative 1 . The basic philosophy seems to be here that the state's sovereign right to expropriate cannot be curtailed by treaty or customary law, but must be exercised in accordance with its own laws and commitments:

"A Contracting State may exercise its sovereign rights in the matter of . . . expropriation . . ., subject . . . to the provisions of its laws. The host State shall abide by and honour any commitments made or assurances given . . . in regard to expropriation and the principles for determination of appropriate compensation ...." 
The World Bank Guidelines, finally, are silent on the effect of assurances on expropriation.

\subsection{Catch-all}

Most of the US BITs include a sort of catch-all condition precedent which requires that the expropriation is "in accordance with the general principles of treatment provided for in Article . ..". The article referred to guarantees fair and equitable treatment, full protection and security, treatment which is not less than that required by international law, and observance of any obligation entered into with regard to investments. The article also forbids impairment of, inter alia, management, operation, use and enjoyment of investments by unreasonable and discriminatory measures. This leaves little room indeed for lawful expropriation. ${ }^{66}$

\subsection{Clarity}

Most Swedish BITs contain a separate requirement, in the form of a condition precedent, to the effect that the measures must be clear, distinct or explicit. ${ }^{67}$ Unfortunately, the meaning of these words in this context is far from clear. This clause occurs in two BITs in our sample: Vietnam-Sweden and China-Greece.

The trouble with a criterion of clarity or distinctness of measures is that it becomes more difficult for arbitrators to decide whether or not a particular taking is lawful. The parties concerned - host country, investor, his insurer

\footnotetext{
${ }^{66}$ See Art. III of the US treaties with Mongolia and Sri Lanka.

${ }^{67}$ The Swedish text of most of the Swedish BITs since 1989 contains the condition that the expropriation measure must be "otvetydiga", which literally means unambiguous or unequivocal. In the BIT with Czechoslovakia (1990) this is translated as clear (Czech: jedneznactá). The Spanish text of the BITs with Bolivia (1990) and Argentina (1991) stipulates "que las medidas sean explícitas". Peru-Sweden (1994) uses the word unequivocal. Six BITs translate otvetydiga as distinct, including the one with Vietnam. There is one other BIT - China-Greece - which has taken over this Swedish clause, translated as clear (I have not been able to check the Chinese and Greek texts). All these treaties, except those with Bolivia and Argentina, are either written in English as the only language or the English text is the one which will prevail if there is a divergence of interpretation. The words clear, distinct and explicit are certainly not synonymous in English, nor do they mean exactly the same as the word unequivocal. It is curious to see how ambiguous language is used in an attempt to forbid ambiguous expropriation measures. Some countries apparently disagreed with the clause, as evidenced by its omission from Sweden's BITs with Morocco (1990), Hong Kong (1994) and Bulgaria (1994).
} 
and the home country - will have to cope with a reduced predictability. Although the requirement of clarity and the like is no doubt meant to protect investors against vague government measures, by making it a criterion of the legality of takings it may in the end prove to be counter-productive.

\subsection{Fair and equitable treatment}

Finally, two Thai treaties of our sample ${ }^{68}$ add a condition which requires that the investor is accorded fair and equitable treatment in relation to any expropriation measure. It precedes three other conditions: those discussed under 5.1, 5.2 and 5.4 above.

\section{THE TERRITORIAL SCOPE OF EXPROPRIATION}

While it is generally accepted that a state has the right, subject to certain conditions, to expropriate foreign-owned assets which are physically available within its territory, the question whether a state can do so with assets situated outside its territory is controversial. A case in point was the nationalization many years ago of foreign oil companies in Zaire, when the question arose what was the legal position of some service stations in neighbouring Rwanda, which were owned and operated by one of these companies. The government of Zaire claimed that these service stations in Rwanda were included in the nationalization and therefore belonged to it, while the oil company concerned relied on the principle that legislative and administrative measures taken by a government in the exercise of its sovereign power cannot have extraterritorial effect. Similar problems often arise when a nationalized company has subsidiaries in other countries. Courts in various countries which have had to deal with such questions have reached different conclusions. ${ }^{69}$

It is therefore of some interest to see what the relevant treaty clauses say on this point. Some of them (fourteen BITs) contain wording to the effect that investments or assets in the territory of the host country will not be expropriated (unless certain conditions are met). The majority (thirty-five BITs), however, is ambiguous, in providing that assets will not be expropriated in the

\footnotetext{
${ }^{68}$ Thailand's BITs with Czechoslovakia and Peru.

${ }^{69}$ In the aftermath of the French nationalizations of 1982, Swiss and Belgian courts came to different conclusions with regard to the right of the newly nationalized French parent company of the St. Gobain group to exercise control over the group's Swiss and Belgian subsidiaries.
} 
host country's territory (again subject to conditions). ${ }^{70}$ Thirteen BITs omit any mention of the territorial scope.

The OECD Convention, like these thirteen BITs, is silent on the territorial scope. But its note on Article 3 nevertheless elucidates the position by referring to the sovereign right of the state under international law to deprive owners of property which is within its territory. Model B, alternative 1 of the AALCC text refers to the state's right of expropriation in respect of investments made in its territory, while the other models refer to investments which shall not be expropriated in the territory of the host state except . . .. The World Bank Guidelines, finally, talk about a state taking a foreign private investment in its territory.

The true objective of the territorial restriction remains obscure, particularly as the clauses of which it forms part are almost always drafted in a negative form. A prohibition to expropriate assets in one's territory unless certain conditions are fulfilled cannot be interpreted as carte blanche to expropriate assets outside one's territory, nor as an absolute prohibition on the expropriation of assets outside one's territory. The prohibition comes from elsewhere. The clause under discussion might just as well have been omitted from all BITs.

The governing principle in my view is the rule of territorial sovereignty and the prohibition of the exercise of extraterritorial jurisdiction which follows from it. A BIT between host state A and home state B cannot infringe the sovereign rights of a third state $C$ in whose territory lie the assets of an investor from B which A claims to have expropriated. What the BIT between $\mathrm{A}$ and $\mathrm{B}$ cannot do is to increase the expropriatory jurisdiction of host state $\mathrm{A}$ at the expense of $C$. What it can do is to reduce A's jurisdiction, e.g. by specifically laying down that assets outside A's own territory may not be claimed by $\mathrm{A}$, not even if they belong to a wholly-owned subsidiary of the investor (a company established in A) which had been nationalized by $\mathrm{A}$ or whose assets had been expropriated by it. This would need specific language and I do not think that the fourteen BITs referred to above are sufficiently specific in this respect. ${ }^{71}$ In any case, a restriction to assets situated within the expropriating state's own territory, if it were specific enough, might safeguard foreign assets (e.g. service stations) owned by the expropriated company itself.

\footnotetext{
${ }^{70}$ This appears to mean that expropriatory measures may not be taken in the host country, rather than that assets within the host country will not be expropriated.

${ }^{71}$ Cf. para. 50 of the ICJ Judgment in the ELSI Case (US $v$. Italy), ICJ Rep. 1989, where the Chamber of the Court indicated that, for lack of a sufficiently high degree of specificity of treaty language, it could not accept the setting aside of an important principle of customary international law such as the local remedies rule.
} 
But in most cases it would offer no comfort if the assets were owned by a foreign subsidiary of the expropriated company, for the shares in the subsidiary which the expropriated company owns are likely to be available in the territory of the expropriating state and therefore within its jurisdiction. This might be otherwise if the shares, in the form of bearer shares, were kept elsewhere so that the expropriating state could not reach them; or, if the assets in question were not owned by a subsidiary of the expropriated company itself, but for instance by a sister company, i.e. a subsidiary of its parent company abroad.

\section{THE OBJECT OF THE EXPROPRIATION}

Ever since the Napoleonic codifications during the early years of the 19th century, expropriation of property has been regulated by the law and often by the constitution of the state. This applied to many European countries and, somewhat later, to Latin America; now virtually everywhere. The object of an expropriation often was, and still is, a specific piece of real property required for a public purpose. It is only in 1917, during the Russian revolution, that large-scale expropriations of whole industries, usually referred to as nationalization or socialization, gave a new face to this old institution.

The authors of BITs have been concerned with wholesale dispossession, rather than expropriation of a single piece of land or other asset. The word whereby the object of the expropriation is indicated in the BITs is almost always 'the investment' (or investments); or occasionally 'investment assets'. The World Bank Guidelines are the only source where I have found a reference to the taking in whole or in part of an investment. The OECD Convention speaks of the property of the investor and makes clear that this property is the object of protection. The notes add that property is used here in the widest sense and includes contractual rights. It is in fact defined in considerable detail elsewhere in the Convention (just as investment is defined in detail in virtually all BITs).

There are ten BITs ${ }^{72}$ in the sample where not only investments but also 'returns' are protected under the expropriation clause. This is curious, because returns usually means profit ${ }^{73}$; which may either have been repatriated (in

\footnotetext{
${ }^{72}$ They include the Italian BITs with Korea, Bangladesh, Vietnam and Mongolia; and ChinaKorea, Japan-Turkey, Korea-Spain, Malaysia-Denmark, Philippines-Spain and Vietnam-Sweden. ${ }^{73}$ The term returns is variously defined in the BITs and, besides profit and dividends, sometimes includes gross income, royalties, interest and other forms of cash income.
} 
which case it is out of reach of the host country) or is waiting in a bank account for repatriation or spending or it may have been re-invested, i.e. added to the assets of the enterprise which forms the investment. Only in the lastmentioned case there could be a possibility of expropriation, i.e. taking of assets, and therefore a case for protection. A sum of money in a bank account is not, or should not, be an object of expropriation as this concept has been interpreted in most BITs as a taking in the public interest and against compensation representing the value at the time of the taking. Obviously, an investor should be protected against theft of money by the authorities of the host country, but the expropriation clause seems the wrong place to do it, and 'returns' the wrong connecting point. The fair treatment clauses of most BITs would seem to afford adequate protection against such abusive government conduct. If the object of expropriation is the local company of the investor rather than the assets of that company, any moneys held by the company in cash or in bank accounts would obviously be included in the expropriation and it would be unnecessary to mention returns as a separate object of expropriation.

Indonesia-Italy, at least, is clear on this point: it includes as an object of expropriation (and therefore of protection against expropriation): income from an investment re-invested in the same investment.

Two $\mathrm{BITs}^{74}$ include another item under the objects of expropriation and protection against it, viz. liquidation proceeds acquired by the investor when he winds up the enterprise in question. Here again, it seems to me a contradictio in terminis to speak of expropriation of a sum of money.

The origin of the clause which brings returns and liquidation proceeds within the scope of the expropriation provision lies in Italy and Sweden. Since Egypt-Sweden (1978), most of the Swedish BITs have included this feature. ${ }^{75}$ Since 1987 the same two items also appear in at least twelve Italian BITs. ${ }^{76}$

\section{COMPENSATION}

The question of compensation being the most important and most controversial issue - historically, politically and economically - with which BITs are

\footnotetext{
${ }^{74}$ Bangladesh-Italy and Vietnam-Sweden.

${ }^{75}$ Including those with Pakistan (1981), Sri Lanka (1982), Bolivia and Czechoslovakia (1990), Latvia, Lithuania and Estonia (1992), Bulgaria and Belarus (1994). Curiously, the BIT with Belarus omits the liquidation proceeds and refers to returns only.

${ }^{76}$ Those with Hungary and Kuwait (1987), Korea (1989), Uruguay, Bangladesh, Bolivia, Vietnam, Venezuela and Czechoslovakia (1990), Albania (1991), Mongolia and Chile (1993).
} 
concerned, we should now look at it in more detail. After a brief introduction about the myth and reality of the HULL formula, we shall deal with the twin 'standards' applied to compensation and valuation, respectively; the point in time relevant to valuation and its fine-tuning; time constraints; payment of interest; and effectiveness of the compensation.

\subsection{The HuLl formula: myth and reality}

When in December 1937 Mexico nationalized its oil industry, a dispute arose with regard to compensation. In 1938 US Secretary of State CORDELL HULL, in a letter to the Mexican ambassador in Washington, set out the US understanding of the legal position in the following words: "Under every rule of law and equity, no government is entitled to expropriate private property, for whatever purpose, without provision for prompt, adequate and effective payment therefor". The hallowed words prompt, adequate and effective have become the flagstaff of American policy regarding expropriation and have remained so till this day. They are today regarded by governments of a number of countries ${ }^{77}$ as the true minimum standard of compensation in international law, known as the 'triple standard'.

As we indicated in section 5.1 above, a large majority of developing states have disputed this claim for an international law standard. In debates during the 1960 s and $1970 \mathrm{~s}^{78}$ in the UN about the concept of permanent sovereignty, a new international economic order and the economic rights and duties of states, the Group of 77 (developing countries) emphasized the right of states to expropriate. At the hight of the debate, in the early 1970s, extremist views on compensation prevailed, ${ }^{79}$ leaving it to the expropriating state to determine what (if any) compensation should be paid and denying that this was a matter governed by international law. Compensation which states should pay was characterized as 'appropriate compensation'.

Thus each of the two doctrines has its own hall-mark: prompt, adequate and effective, and appropriate compensation, respectively. Neither means

\footnotetext{
${ }^{77}$ See n. 44 above.

${ }^{78}$ See SCHRIJVER (1995), Chapter 3.

${ }^{79}$ See Art. 2 of CERDS which reads in part: "Each State has the right: . . . to nationalize, expropriate . . . foreign property, in which case appropriate compensation should be paid by the State . . ., taking into account its relevant laws and regulations and all circumstances that the State considers pertinent. In any case where the question of compensation gives rise to a controversy, it shall be settled under the domestic law of the nationalizing State and by its tribunals, unless it is freely and mutually agreed by all States concerned that other peaceful means be sought . ..".
} 
anything specific, these expressions have become symbols identifying the opposing forces. A number of countries have remained neutral on this battlefield and abstain in their BITs from using either expression.

It is indeed remarkable how devoid of meaning both expressions are. On the one side, 'adequate', which gives no indication at all of the amount of money that should be paid. The word suggests that something less than 'full' compensation (i.e. the full value of the assets taken) ought to be paid, but this is unlikely to have been HULL's intention. The word 'prompt', if taken literally, would be meaningful, but state practice as well as the explanatory wording in the BITs themselves make it clear that a literal interpretation is not intended (see section 8.5 below). The word 'effective' has a clear meaning in the context, but it can only be understood in the light of a historical interpretation. On the other side, 'appropriate' compensation is just as unhelpful. It gives no cue of what an arbitrator should look for, even less so than most of the other qualifications used in this context (see section 8.2 below).

We recall that the OECD Convention did not embrace the HULL formula, but requires "provision for the payment of just compensation". The AALCC Model A does call for "prompt, adequate and effective" compensation; while Model B wants "payment of appropriate compensation" in alternative 1 and "prompt payment of appropriate compensation" in alternative 2. The World Bank Guidelines, it may be recalled, ${ }^{80}$ try to get the best of both worlds by asking for "payment of appropriate compensation", followed by a clause equating appropriate compensation with compensation which is adequate, effective and prompt.

A review of our sample of sixty-two recent Asian BITs shows that nineteen of them contain a full-fledged HULL formula. Five contain an 'improved' triple standard which is clearly inspired by HuLL ${ }^{81} \mathrm{~A}$ further ten contain two of the three elements of HULL, usually 'adequate and effective', thus still clearly reminiscent of HULL. These make a total of thirty-four HULL-based BITs. ${ }^{82}$

In a sample of 282 BITs worldwide the following countries are found to be the main protagonists of the HULL formula: US, UK, Australia, Canada,

\footnotetext{
${ }^{80}$ See section 5.1 above, in fine.

${ }^{81}$ Instead of prompt, adequate and effective, the qualifications full, immediate and effective have been adopted in these 5 BITs (Bangladesh-Italy; Indonesian BITs with Italy, Korea and Netherlands; Mongolia-Italy). 'Full' compensation may be felt to give better protection than 'adequate' compensation. 'Immediate' expresses even greater urgency than 'prompt'.

82 The strong position of the HuLL formula is confirmed if the same analysis is made on a larger sample of 282 BITs worldwide, entered into or brought into force since 1980 . The number of BITs in this sample with a classical HULL formula is 105. In addition, there are 11 with a reinforced HuLL formula (full instead of adequate compensation) and 43 with two of the three elements. This shows a total of 159 or $56 \%$ with a clearly recognizable affinity to HuLL.
} 
and three of the four Scandinavian countries (Denmark, Finland and Sweden, but not Norway). France and Switzerland consistently favour formulas with two of the three HuLL elements: prompt and adequate in the case of most of the French BITs, adequate and effective in the Swiss BITs. Countries with a less pronounced predilection for HULL include Italy, Korea and Turkey. The main HULL antagonists appear to be Austria, China, Germany, the Netherlands, Norway and Spain. Indeed, until recently most of the developing countries had a natural disinclination towards HULL and what it stood for. Morocco stood firm against the US (1990) and is its only BIT partner which succeeded in getting a (small) deviation from HULL ('just' instead of 'adequate'). In 1990 Morocco stood up against the standard UK wording as well and got a clause with 'fair and equitable' compensation. ${ }^{83}$ China has from the outset stuck out against HULL. It has never accepted it, not even from a country such as Australia, which has it in all its other BITs. ${ }^{84}$

On the other hand, some countries with a strong preference for HULL got it included notwithstanding the other country's obvious dislike: a case in point is Kuwait which had it included in its BIT with Germany, a country which in more than ninety BITs has consistently (apart from this one exception) used its own, quite different, formula. Similarly, Estonia and Latvia persuaded Norway, a country averse to HULL, to include the HULL formula in their BITs. Curiously, Lithuania - which in all other respects made common cause with the other Baltic republics in BIT negotiations - did not get the HULL formula in its BIT with Norway.

All the above goes to show how much importance is attached by a great many countries to the magic of the HULL formula. Politically, indeed ideologically, it is a reality which plays a role in negotiations. As to substance, it is a myth, mere eyewash. This will become clear when we look at the detailed terms of BITs with a HULL formula, as far as promptness (section 8.5 below), adequacy (section 8.2 below) and effectiveness (section 8.7 below) of compensation are concerned.

\footnotetext{
${ }^{83}$ Other persistent objectors against the HuLL clause include Romania which resisted, inter alia, the Danish Hull formula (1980); Egypt which stood up against France (1974); Bulgaria against Italy (1988); Bulgaria and Albania against Switzerland (1991/92); and Ghana against the UK (1989). In most of these cases compensation was promised without any qualifier, or with a neutral (and more meaningful) word such as 'just'.

${ }^{84}$ See SORNARAJAH (1994) 257 at n. 83, where he incorrectly states that China made an exception for Australia.
} 


\subsection{Standards of compensation and valuation: the qualifying adjectives}

Most BITs use two adjectives in the compensation formula: one to qualify the compensation due to the expropriated investor and one to qualify the value of the investment for which compensation has to be paid. Some omit all adjectival embellishment, ${ }^{85}$ others need more than one descriptive term on each side of the equation.

In our sample of sixty-two BITs we found - apart from the nineteen BITs with 'prompt, adequate and effective', the ten with 'adequate and effective' or 'prompt and adequate', and the one with 'appropriate' compensation, ${ }^{86}$ - the following: three with adequate, one with effective, three with fair, five with full and five with just compensation. None of these epithets adds anything to the meaning of the concept 'compensation', except perhaps 'full' compensation which emphasizes that it is the intention that the investor's loss should be compensated in toto, and not merely in part. ${ }^{87}$

If the above record is compared with the world-wide sample of 282 BITs (see n. 82), a striking feature is again the large number of BITs where no epithet is used (65). This is largely due to Austrian, German and Norwegian BITs. Otherwise this analysis yields the following picture: apart from 102 complete and forty-seven partial HULL formulas, 'adequate' occurs in fourteen, 'appropriate' in one, 'effective' in two, 'fair' or 'reasonable' in six, 'full' in two and 'just' or 'equitable' in twenty-five BITs. So far about qualifiers of compensation, we now turn to qualifiers of value.

The distribution of qualifying adjectives relating to the relevant value is as follows in the two samples of sixty-two and 282 treaties of which respectively fifty-nine and 274 have a value clause:

\footnotetext{
${ }^{85}$ The Chinese treaties excel in soberness. Six of them (with Mongolia, Portugal, Spain, Albania, Georgia and Estonia) merely promise compensation equal to the value of the investment. Three others (with Greece, Philippines and Uruguay) refer to fair or reasonable compensation equal to the value. Maximum soberness is also shown in Mongolia-Germany and Vietnam-Germany. It should be noted that virtually all German BITs of the last 15 years, world wide, use this sober formula, as do most Austrian and Norwegian BITs.

${ }^{86}$ China-Laos. Earlier also used in China-France (1984) and China-Thailand (1985), but these earlier BITs are not included in our sample.

${ }^{87}$ In practice partial compensation, according to the literature, is the rule rather than the exception. This is certainly true for final settlements laid down in international lump sum agreements. The outcome of settlements achieved through direct negotiation or arbitration is, however, seldom published and reliable data are usually not available. SORNARAJAH (1994) at 363 and 401 concludes that compensation is usually partial and that international law does not require full compensation in case of a major nationalization. The present writer does not share this view.
} 
none:

14 / 87x e.g. most German and Austrian treaties

market value:

20 / 68x e.g. many Scandinavian and Australian BITs

fair (market) value:

$10 / 29 x$ in particular US treaties

genuine (market) value: $1 / 18 \mathrm{x}$ in particular UK and Netherlands treaties

real value:

actual value:

$13 / 43 x$ in particular French treaties

normal value:

$1 / 4 \mathrm{x}$

effective value:

$0 / 3 \mathrm{x}$ partly attributable to Turkey

full value:

$0 / 2 \mathrm{x}$

just value:

$0 / 2 \mathrm{x}$

$0 / 1 \mathrm{x}$

Some of the BITs which refer to market value add a further clause with instructions how the value is to be ascertained in the absence of a market value. We shall revert to this point in section 8.4 below. In Papua New Guinea-Australia the reference is to the market value of the investment 'as a going concern'. This emphasizes, as we mentioned above, that the provisions made in BITs regarding expropriation, under whatever name, almost always disregard the possibility that a government may expropriate a single asset such as a piece of land, a building or a patent. ${ }^{88}$

In the circumstances surrounding most real-life expropriations a reference to market value will seldom be of use, as normal market mechanisms will usually be thoroughly disturbed. Nor will most of the other qualifying terms be of much help to arbitrators called upon to establish the value. The word 'normal' may be taken to indicate that the value to be established must be the value in normal circumstances and not that in the disturbed circumstances which resulted from (or gave rise to) the expropriation. ${ }^{89}$ The word 'actual' is positively misleading. This word has many meanings in the English language (and is often used without any meaning at all), including "existing at the time, current". ${ }^{90}$ The intention here is, on the contrary, to establish the value at an earlier point in time, i.e. when circumstances were still normal (see section 8.3 below).

\footnotetext{
${ }^{88}$ BITs also disregard partial expropriations whereby the government of the host country seeks to acquire a percentage, for instance $51 \%$, of the investment as a whole. In this way the government may get control but arguably need pay as compensation only $51 \%$ of the value. Expropriations of this type were started by Libya in the early 1970s. Understandably, companies thus deprived of control of their investment and forced into a joint venture, consider such measures unacceptable and unlawful.

${ }^{89} \mathrm{Cf}$. the France-Nigeria BIT which spells it out by requiring the real value in normal circumstances.

${ }^{90}$ According to the Shorter Oxford English Dictionary this is one of the main and oldest meanings.
} 
To illustrate this review of terms, we quote below some examples, mainly from our sample of BITs. The confidence of the investor is likely to depend on the precise language used. The mandatory wording ('shall') of the first example (the OECD Convention), together with the requirement of a 'provision' (a budgetary allocation) at the time of the measure and the reassuring words 'just' and 'genuine', are likely to inspire more confidence than the loose wording of the Thailand-Czechoslovakia BIT, quoted at the end, where market value only needs to be 'taken into account', together with other, unnamed, factors:

- "The measures are accompanied by provision for the payment of just compensation. Such compensation shall represent the genuine value of the property affected . . ." (Art. 3 OECD Convention, 1967);

- “. . . against prompt payment of appropriate compensation. . . ' 'appropriate compensation' shall mean compensation determined in accordance with equitable principles taking into account the capital invested, depreciation, capital already repatriated and other relevant factors" (Art. 7 AALCC Model B, alternative 2, 1984);

- “. . . against the payment of appropriate compensation. Compensation for a specific investment taken by the State will . . . be deemed 'appropriate' if it is adequate, effective and prompt. Compensation will be deemed 'adequate' if it is based on the fair market value of the taken asset . . " (paragraph 4 World Bank Guidelines, 1992);

- ". . against adequate and effective compensation. Such compensation shall amount to the market value of the investment . . . expropriated on the day the measure was taken . . ." (Art. 5 Korea-Thailand, 1989);

- “. . . against compensation. The compensation . . . shall be in accordance with the laws and regulations of the Contracting Party taking expropriatory measures ..." (Art. 4 China-Pakistan, 1989);

- “. . . against compensation. The compensation ... shall be such as to place the investors in the same financial position as that in which they would have been if the measures . . . had not been taken" (Art. 4 China-Argentina, 1992);

- "the measures are accompanied by provisions for the payment . . o of fair compensation. Such compensation shall amount to the value of the investments affected . . . The compensation shall be calculated in such a way as to place the investor in the same financial position in which he would have been, had the measures . . not been taken" (Art. 4 China-Greece, 1992); 
- "against payment of compensation. Such compensation shall be adequate, taking into account, inter alia, the market value" (Art. 6 ThailandCzechoslovakia, 1991).

Some further examples are given below from recent non-Asian BITs:

- Article 4 Norway-Romania (1991) requires, by way of condition precedent, that "A proper procedure is established to determine the amount and method of payment of compensation". This is followed by: "The compensation shall correspond to the value of the investment ... and shall be prompt, adequate and effective. The amount of compensation shall be determined in accordance with recognized principles of valuation, such as the market value of the investment . . . In case the market value cannot be ascertained, the compensation shall be determined on the basis of equitable principles taking into account, inter alia, the capital invested, its appreciation or depreciation, current returns, replacement value and other relevant factors . ..". These clauses can be identified as of Romanian origin, as almost the same wording is used in Article 4 Italy-Romania (1990), except that 'market value' is replaced there by 'effective and fair market value' and in the HuLL clause the weaker word 'should' is substituted for 'shall'.

- "The measures are taken against just compensation. Such compensation shall represent the genuine value of the investments affected" (Art. 6 EstoniaNetherlands, 1992); Article 6 Latvia-Netherlands (1994) has the same text except that fair market value replaces 'genuine'.

- "vorausgesetzt, dass eine wertentsprechende . . Entschädigung vorgesehen ist" (Art. 7 Albania-Switzerland, 1992).

- “. . . mediante indemnização. A indemnização deverá corresponder ao valor que o investimento expropriado tinha à data da expropriação" (Art. 10 Cape Verde-Portugal, 1990).

- “. . . contro immediato, pieno, ed effettivo risarcimento . . . Il giusto risarcimento sarà equivalente all'effettivo valore di mercato dell'investimento ..." (Art. 5 Bolivia-Italy, 1990).

\subsection{The relevant point of time for valuation}

Compensation requires valuation of the assets expropriated. In the previous section we reviewed the general terms whereby the compensation and valuation are often qualified. We concluded that most of the terms used throw little if 
any light on the valuation process required. In this section we will consider the time element and see how various BITs have sought to define or clarify it. In the next, finally, we will analyze other detailed arrangements introduced into BITs by way of fine-tuning the process.

Most of the sixty-two BITs in our sample contain a clause indicating what is the point in time for which the value of the investment has to be assessed, seven are silent on this question. The others use expressions such as:

(a) on the day when the measure was taken (1x);

(b) at the time of (or just before) the expropriation (2x);

(c) at the time when the expropriation is proclaimed (12x);

(d) before the expropriation became known $(13 \mathrm{x})$; $^{91}$

(e) before the expropriation or impending expropriation became public knowledge (27x).

Only the last two formulas recognize that the value is likely to be affected by the very expropriation for which compensation is to be made, and of course by any rumours or expectations about it. None of them are of much use in case of a 'creeping nationalization' consisting of government measures spread over a long period, e.g. delaying import authorizations or any other procedures on which the business of the investor depends, perhaps with the intent that the investor give up his business, so that expropriation is no longer necessary, or perhaps precisely in order to reduce the amount of compensation the government would have to pay. Such malpractices are not unknown in the business world when mergers or take-overs are planned and there is no reason to think that they could not exist when state-owned companies and governments are involved.

The conclusion must be that the clauses under discussion, if taken literally, are likely to be ineffective in many cases of expropriation, particularly when there is no 'proclamation'. The formula we quoted as the penultimate example at the end of section 8.2 above ("to place the investor in the same financial position in which he would have been, had the measures . . . not been taken") would be a better way of helping arbitrators to achieve the intended result. Even so, this formula disregards the possibility that, long before the expropriation in question, the investment climate may have been thoroughly disturbed by other expropriations or threats thereof. ${ }^{92}$ A clear-cut formula is contained in the French BITs with Vietnam and Mongolia: “. . . par rapport à une situation économique normale et antérieure à toute menace de dépossession”.

\footnotetext{
${ }^{91}$ In Sri Lanka-US this is further elaborated in a protocol by clarifying that the expression "became known" is intended to refer to any knowledge resulting in the diminution of the fair market value.

${ }^{92}$ See the discussion immediately below on the OECD Convention.
} 
The time problem first cropped up during the early $1970 \mathrm{~s}^{93}$ and about half of the one hundred-odd BITs concluded up to 1982 tried to find a remedy on the lines indicated under sections 8.1 to 8.5 above. It is indeed surprising that most BITs concluded during the first half of the 1990s have still not found an effective solution!

The OECD draft Convention did not deal with this problem in its Article 3 on taking of property, but did refer to the question in the notes and comments on this article. On the genuine value of the property affected it is said that "the value must remain unaffected by artificial factors such as deterioration due to the prospect of the very seizure which ultimately occurs, similar seizures by the Party concerned or the general conduct of that Party towards property of aliens which makes such seizures likely". It is remarkable that, apart from the French BITs with Vietnam and Mongolia quoted above, none of the BITs analyzed covers the two last-mentioned causes of deterioration: preceding expropriations of others' investments by the same country, and its general conduct.

AALCC Model B did not deal with the problem at all, but Model A prescribed that compensation "shall be computed on the basis of the investment immediately prior to the point of time when the proposal for expropriation had become public knowledge".

The World Bank Guidelines go into greater detail on the question of compensation than any BIT has done so far. They first provide that compensation will be deemed adequate:

"if it is based on the fair market value . . a as such value is determined ${ }^{94}$ immediately before the time at which the taking occurred or the decision to take the asset became publicly known."

It is further provided that the host country, if called upon to determine the compensation, may reasonably do so in the case of assets which are neither a profitable going concern, nor an economically unviable enterprise, on the basis of replacement value or, in case the book value has been recently assessed or has been determined as of the date of the taking, on the basis thereof.

\footnotetext{
${ }^{93}$ See France-Zaire (1972).

${ }^{94}$ This should no doubt be interpreted as meaning that, whenever the determination is made, it must relate to the value at the time indicated. The words used, if taken literally, would mean that the determination (assessment) itself must have been made at the time indicated. It should be observed that the formula quoted is not a conditio sine qua non but is flexible. If the condition is fulfilled, the compensation will in any case be deemed adequate. If it is not fulfilled, there is nothing to prevent arbitrators from still finding compensation adequate.
} 


\subsection{Fine-tuning of valuation procedures}

Even though the BITs of our sample do not display the wide range of possibilities for valuation which one can find in the World Bank Guidelines, nevertheless - or, perhaps, precisely for that reason - it is worthwhile to look in some detail at their rules on valuation. The Guidelines, of course, were drafted later than most of the BITs under review and may be regarded as an attempt to formulate the greatest common denominator of all the different procedures one can find in treaty practice. Before going into the nitty-gritty of rules on valuation, we want to give some thought to the principles at stake and the practical problems faced by those involved: (a) the government of the expropriating country, which normally is the host country; ${ }^{95}$ (b) the investor who has suffered expropriation; (c) the investor's home country which may be entitled to give diplomatic protection to the investor and whose own national interests may be at stake; (d) courts and arbitral tribunals called upon to deal with disputes about compensation; (e) legal advisers of the parties.

The literature on expropriation and compensation is abundant, ${ }^{96}$ but most of it has been written by academics from an academic or political rather than from a practical point of view and few of these authors have been personally involved. There are, however, also some valuable contributions by practising lawyers who have been so involved, in particular during the past 15 years, in arbitrations before the Iran-US Claims Tribunal in The Hague. In many cases where disputes were resolved through direct negotiation or by arbitration the full terms of the settlement or award have not been divulged, let alone the arguments and methods by which the final results had been achieved. Lawyers engaged in such negotiations and arbitrations are not prone to publish their experience.

The present author had some experience with expropriations in the oil industry during the thirty years he worked for one of the major oil companies, but this paper is not the place to expand on that experience, nor is he inclined to make public confidential materials which, even after many years, may cause embarrassment to the companies or governments concerned. Inevitably, however, the views here expressed on principles and problems involved will be coloured by this background and experience.

Many expropriations of recent decades have been conducted in reasonable cooperation between the governments and companies concerned. Compensation

\footnotetext{
${ }^{95}$ Not always, see sec. 6 above at $n .69$.

${ }^{96}$ See SORNARAJAH (1994), Ch. 9 and the literature referred to there. See, in particular, LILLICH (1972) and SCHACHTER (1984).
} 
then is a matter of negotiation and although the parties will no doubt calculate different values on a range of possible bases, the final settlement is bound to take account of other considerations as well: the economy of the country (how much can it afford to pay, and how soon?); the legal position (if it is an illegal expropriation the company may seek a higher amount than in the case of a lawful expropriation); recent precedents (the outcome of comparable expropriations in other countries); remedies available if the negotiation fails (international arbitration); future relationship which either or both parties may aspire to (the expropriated company may continue to run the business as a contractor of the state).

There have also been many cases, of course, where relations between the parties were decidedly hostile and which led to highly controversial arbitrations. These bitter disputes inevitably dominate the collective memory and writings about expropriations of the second half of this century. Even in these cases the parties sometimes came together, once tempers had cooled off, and worked out a settlement, usually a package deal including payments in cash and/or in kind, loans, future contracts and other elements, and arbitration proceedings were discontinued. In such cases it is impossible to show in retrospect that the compensation was based on 'market value', 'book value' (whether or not written down, adjusted for inflation or otherwise), or on any other bases and procedures prescribed in BITs, Guidelines or textbooks.

Notwithstanding these reservations, it remains of interest to study the detailed rules and procedures on compensation and valuation set out in BITs and in the World Bank Guidelines, as these are likely to influence negotiations between the parties and deliberations of arbitrators.

As we have seen, most BITs which qualify the value to be established refer to the market value. This is not a recent trend of the post-cold-war period, but had already started in the early 1970 s. $^{97}$ As said above, market value of companies which have been expropriated is seldom relevant, for the simple fact that in most cases there is no market where companies are traded. Even in countries where corporate take-over practices have developed it is rarely possible to identify competition and information on financial conditions and offers without which it is difficult to speak of a market. Market value would be more relevant when the objects of the expropriation consisted of marketable items such as a parcel of land or a building but, as we have seen, it is clear from the wording of most BITs that the expropriation provisions apply to the investment as a whole and not to individual items.

${ }^{97}$ In a sample of 38 BITs of the period 1973-82, ten refer to market value. 
The drafters of the BITs, in using the term market value, may have had a much wider concept in mind, namely the fair value of the investment (company or whatever else might be the object of an expropriation) in the context of a market economy. In other words, at a time when grosso modo the world consisted of two types of countries - the prosperous ones of the 'West', predominantly relying on a market economy, and those of the 'South' and the 'East' with a centrally organized command economy - the words 'market value' were a signpost pointing to the system of market economies. In drafting these provisions little thought seems to have been given to the relevance of market value as such to the problem of determining compensation due by an expropriating state. The OECD Convention avoided this term where it required in Article 3 payment of compensation representing "the genuine value of the property affected". Although, in the notes and comments on this article, it was pointed out that "the genuine value of the property affected" will, as a rule, correspond to the fair market value of the property, the words 'as a rule' indicate that this is not necessarily so. How the genuine value should be established if it does not correspond to fair market value, is left open.

AALCC Model A does take into account the possibility that a market value cannot be readily ascertained and prescribes that in that case the compensation "shall be established on equitable principles taking into account inter alia the capital invested, depreciation, capital already repatriated and other relevant factors". The word 'readily' confuses the issue and had better be deleted. ${ }^{98}$ From the words 'inter alia' and 'other relevant factors' it is clear that the enumeration of factors is open-ended, but the three listed must in any case be taken into account. As we shall see below, several BITs have somewhat extended this list.

As we mentioned in section 5.5 above, alternative 1 of the Model B text leaves it to the parties in each case to agree upon the principles for determination of appropriate compensation, including the mode and manner of payment. Barring stipulations to the contrary, compensation must be calculated on the basis of recognized principles of valuation. The basic duty of the host state is to pay 'appropriate' compensation but this duty is subject to the provisions of its own laws. The host state also must abide by and honour any commitment it has made in regard to the above-mentioned principles, but it remains unclear

\footnotetext{
${ }^{98} \mathrm{Cf}$. the unconscionable extent to which attempts to establish market value may be pursued under the World Bank Guidelines by the simple expedient of extending the definition of market value to include virtually any other type of value or system of valuation (see sec. 8.3 above in fine). The Guidelines, in para. IV. 4, provide that "determination of the 'fair market value' will be acceptable if conducted according to a method agreed by the State and the foreign investor ... or by a tribunal or another body designated by the parties".
} 
whether the commitment to abide takes precedence over the host country laws, and, whether the party with which the host country must agree the principles and vis-à-vis which it is committed is the home country or, more sensibly, the investor. In summary: rules about valuation are not included in the Model text but are left to be made later, presumably when the investment contract is entered into; the host state appears to be bound thereby, but this is not quite clear.

The corresponding alternative 2 starts out on the basis of the HULL formula, then prescribes that - barring stipulations to the contrary - compensation must be calculated in accordance with equitable principles, taking into account the capital invested, depreciation, capital already repatriated and other relevant factors, i.e. virtually the same as in Model A.

Two thirds of the sixty-two BITs of our sample ${ }^{99}$ do not contain procedural rules such as those set out in the instruments discussed above. Ten follow the pattern of AALCC Model A, with minor variations. The starting point is market value, but when this cannot be 'readily ascertained' the instruction is to establish the compensation on the basis of 'generally recognized principles of valuation' and equitable principles, taking a number of specific factors into account plus any other factors which may be relevant. The 'generally recognized principles of valuation' have been added to the AALCC formula, presumably to avoid disputes about the equitable nature of valuation practices. AALCC's three specific factors (capital invested, depreciation and capital repatriated) are included in nine out of the ten BITs. The exception is the Indonesia-Italy BIT, which - for reasons unknown leaves out the factor 'capital repatriated' and is exceptional in other respects as well. The Indonesian clause in question is as follows:

“. . . compensation shall amount to the real market value . . . Such amount shall be calculated according to the method agreed upon by both parties in conformity with international [sic!] acknowledged evaluation standards. In case that the real market value cannot be easily ascertained, the compensation shall be determined on equitable objective principles, taking into account, inter alia, the capital invested, its appreciation or depreciation, current returns, replacement value and any other relevant factor mutually agreed upon"100 (this English text is the prevailing text of the treaty).

\footnotetext{
${ }^{99} \mathrm{Viz} .13$ out of 17 Chinese treaties, 4 of 5 Hong Kong, 3 of 4 Indonesian, 10 of 11 Korean, 6 of 8 Vietnamese treaties and 7 out of the 12 other treaties.

${ }^{100}$ The Indonesian treaties show a preference for things to be left open for agreement between the parties when the time comes, rather than spelling them out in the treaty. See also $n$. 115 below on the musyawarah practice and philosophy.
} 
The confusion that may be caused by the word 'easily' has been commented upon above. The phrase "agreed upon by both parties" may also cause confusion. In the context 'parties', even though not written with a capital P, is likely to be understood as the Contracting Parties. As a practical matter there is no need for explicit agreement, and certainly not agreement of the two countries, as this would hamper arbitrators ${ }^{101}$ who may be called upon to resolve a dispute which could arise on this point between the parties most concerned, namely the host state and investor. The same problem exists with regard to the words 'mutually agreed upon' at the end of the quote. The insertion of 'objective' needs no comment. The addition of 'appreciation' is odd as it would seem to change the sense of the term 'depreciation' retained from the AALCC formula. The AALCC used 'depreciation' in the normal accounting sense, i.e. the amount amortized or written down on the capital invested. The corresponding accounting concept in an upward direction, by a revaluation or upgrading of the value of certain assets whose market value has increased, might be called appreciation but is so exceptional that a reference to appreciation or depreciation of capital is more likely to be understood as changes upward or downward in the value of capital held in currency, as a result of deflation/inflation or of revaluation/devaluation of currencies in the monetary sense. Such ambiguity is regrettable.

Nine of the ten BITs have added 'replacement value' 102 as a factor, five have added 'currency exchange rate movements' ${ }^{103}$ and one has added 'goodwill'. ${ }^{104}$

Finally, what do the World Bank Guidelines have to say about this? The criteria listed there for determining the fair market value are: the amount that a willing buyer would normally pay to a willing seller after taking into account the nature of the investment, the circumstances in which it would operate in the future and its specific characteristics, including the period in which it has been in existence, the proportion of tangible assets in the total investment and other relevant factors pertinent to the specific circumstances of each case. In the case of a going concern with a proven record of profitability, the fair

\footnotetext{
${ }^{101}$ If the dispute hinges on a particular accounting standard which arbitrators and the investor consider relevant, the arbitrators may be precluded from applying it if the host country objects. If the standard is favoured by the host country but opposed by the investor, arbitrators would have to decide whether agreement is required from the investor or from the home country (which may hold different views and may have different interests).

${ }^{102}$ China-Slovenia; the Australian BITs with Vietnam, Hong Kong, Indonesia, Papua New Guinea, Laos and Philippines; and the Italian BITs with Vietnam and Indonesia.

${ }^{103}$ The Australian BITs with Vietnam, Hong Kong, Indonesia, Laos and Philippines.

104 Vietnam-Italy.
} 
market value could be the present value of the discounted cash flow, ${ }^{105}$ using a discount rate reflecting the time value of money (i.e. a reasonable long term interest rate) as well as inflation and risks. The system described in the Guidelines would seem to be more realistic than that set out in most BITs.

\subsection{The time constraint}

Under the HULL formula compensation should not only be adequate and effective but also prompt. Virtually all clauses on compensation provide for timely payment. But what is timely? 'Prompt', usually translated into French or Spanish as 'immédiatement' or 'de inmediato', is used in many BITs, as we have seen, as part of a HULL formula (in whole or in part), but is often gainsaid in the next sentence by using a more indulgent expression, such as 'without undue delay' or 'as soon as possible'. Altogether in eleven BITs the promptness of a HULL formula has been toned down in this way. A remarkable example is Korea-USSR where prompt compensation was translated into payment within two months after expropriation and it was further provided that interest would accrue if after the two-months period payment had not yet been made.

Apart from the HULL formula, where 'prompt' is part of a ritual expression and must not be taken literally, the three degrees of urgency encountered in our BITs are: immediate or prompt (2x), without delay (21x) and without undue delay ${ }^{106}(35 \mathrm{x})$. Although 'without delay' has a degree of sternness about it which is lacking in 'without undue delay', at a closer look the difference may be deceptive. For instance Nepal-UK prescribes 'without delay' but adds 'in any event not later than six months after the date of expropriation', while Hong Kong-Denmark requires payment "without undue delay which, in any event, shall not extend [sic!] a period of three months".

Another formula which is sometimes used to indicate business on a cashdown basis requires that the expropriation measure is 'accompanied by pay-

\footnotetext{
${ }^{105}$ According to the Guidelines the cash flow should be estimated on a forward basis, presumably (but this is not defined) from the day when the expropriation becomes effective (the day of taking) to the end of its economic life. An alternative would be a present value based on the cash flow over the whole period from commencement of the investment up to the end of its economic life, with past (actual) cash flow figures being adjusted upward by the same discount rate as future estimated figures are discounted downward. In either case the present value calculated is the value at the day of taking.

106 Or: without unreasonable delay.
} 
ment' of compensation (as further defined). ${ }^{107}$ The more usual formula which requires that the expropriation measure should be accompanied by 'provision(s) for compensation' ${ }^{108}$ does not contain a commitment to pay by a given date or within a given period, it merely means that at the date of the expropriation the expropriating state must have the money available or at least have fixed the whole procedure. ${ }^{109}$

Perhaps the most realistic means of protecting the investor against delay in compensation is an obligation for the state to pay interest. This will be discussed in the next section.

\subsection{Payment of interest}

If payment of compensation is required promptly or without delay it may seem inconsistent explicitly to require payment of interest in case of delay, i.e. when the state is in default. A court or arbitral tribunal may be expected to award damages to the investor in case of default and these should normally be equal to interest at a normal commercial rate. If compensation must be paid without undue delay, a specific clause on interest to be paid during the period between expropriation and payment of compensation would be logical. In practice compensation is hardly ever paid promptly or without substantial delay, sometimes ten years or more, and payment of interest at a rate which reflects inflation and the time value of money thus becomes an important element of compensation.

The OECD Convention did not have an interest clause. Neither did more than $80 \%$ of BITs concluded before 1982. The initiative for including an

\footnotetext{
${ }^{107}$ Australian BITs with Indonesia, Laos, Philippines and Vietnam. The tautology in a requirement for expropriation to be "accompanied by prompt, adequate and effective compensation" illustrates the merely symbolic function of the HuLL formula.

${ }^{108}$ As pointed out above (see n. 13), the word 'provision' in this formula is sometimes used in the plural (provisions), thereby acquiring another meaning. The original intent in the OECD Convention appears to have been that a government, before taking an expropriationary measure, should make budgetary provision (i.e. reserve the money) to ensure that just compensation could be paid.

109 This formula is used in China-Greece, Vietnam-Sweden and Papua New Guinea-Australia. A similar provision can be found in Vietnam-Germany and Korea-Austria: "Provisions for the determination and payment of such compensation shall be made in an appropriate manner not later than at the moment of the expropriation". Cf. Korea-Romania where the establishment of a proper procedure to determine the amount and method of payment of compensation is a condition precedent.
} 
interest clause seems to have lain in most cases with the developing countries, in particular Asian countries such as Korea, Singapore and Sri Lanka. ${ }^{110}$

The AALCC Model A included a clause that "compensation shall include interest at a normal commercial rate from the date of expropriation until the date of payment". The World Bank Guidelines require in normal circumstances payment of compensation without delay, but in certain defined exceptional circumstances allow payment in instalments "provided that reasonable, marketrelated interest applies to the deferred payments in the same currency", i.e. the currency brought in by the investor or a freely transferable currency.

Compared with the $20 \%$ of pre-1982 BITs which provided for interest, there has been a sharp increase in our sample of sixty-two post-1990 Asian BITs, of which forty (i.e. 63\%) carry an interest clause. ${ }^{111}$ Most of these follow the wording of the AALCC clause (interest at a normal commercial rate from the date of expropriation until the date of payment), but in one BIT (Korea-USSR) interest does not become due until two months after expropriation.

Various formulas have been used to specify the rate of interest to be paid. In four BITs the rate is related to LIBOR. ${ }^{112}$ Laos-France specifies the official Special Drawing Rights interest rate fixed by the IMF. Sometimes it is specified that the rate to be used is the current rate applicable to the currency brought in for the investment, ${ }^{113}$ while in other cases the rate applicable to the host country currency is to be used. ${ }^{114}$ Vietnam-France prescribes a rate to be agreed between the Contracting Parties, i.e. Vietnam and France. Such a procedure is detrimental to the investor and likely to cause delay as the debtor state has no interest in coming to a quick agreement unless the rate is favourable to it. ${ }^{115}$

\footnotetext{
${ }^{110}$ While more than $90 \%$ of German and Swiss BITs did not include an interest clause in those early years, the German treaties with Mali (1977), Oman (1979) and Papua New Guinea (1980) and the Swiss treaties with Korea (1971) and Sri Lanka (1981) did. So did the BIT between Korea and Sri Lanka (1980) and Japan-Egypt (1977).

${ }^{111}$ The abstainers include all but three of the 17 Chinese BITs and four out of eleven Korean BITs.

${ }^{112}$ The London Inter-Bank Offered Rate (published daily for 1 to 12 months periods) is indicated in three of the five Italian BITs (with Bangladesh, Mongolia and Vietnam) and Vietnam-Denmark. ${ }^{113}$ China-Slovenia and World Bank Guidelines.

${ }^{114}$ Hong Kong-Sweden indicates the rate applicable under the law of the host country.

${ }^{115}$ A similar clause is to be found in Indonesia-Italy: the rate has to be agreed - it is unclear whether it is the investor or its home country which should reach agreement with the host country - "according to the prevailing rates". Indonesia-Australia prescribes an agreed "commercially reasonable rate". This must have been inspired by the concept of musyawarah, one of the pillars of the Pancasila philosophy underlying the Indonesian Constitution of 1945 , which requires consensus or exhaustive negotiation. Malaysia-Denmark, too, wants "an appropriate rate as
} 
In two Korean BITs the interest clause appears to be ineffective as a result of peculiar drafting. ${ }^{116}$ For religious reasons a number of Islamic countries have traditionally been averse from interest clauses. Thus Bangladesh, Egypt, Morocco, Oman, Pakistan and Tunisia have concluded BITs without a normal type of interest clause, although all of them except Morocco and Tunisia have on occasion deviated from this policy. ${ }^{117}$ Other Islamic countries, on the other hand, have shown a predilection for BITs with an interest clause. ${ }^{118}$

There are three Multilateral Investment Treaties (MITs) with exclusively Islamic membership: the 1980 Arab League Treaty of Amman for the Investment in Arab States (21 member states); the 1981 Treaty of Baghdad of the Organization of the Islamic Conference ( 46 member states) for the promotion, protection and guarantee of investments among member states, signed by at least 18 of the 46 states $^{119}$ and in force since 1988; and the 1990 Treaty of the Arab Maghreb Union (5 member states) on promotion and protection of investments. In addition there is a fourth investment MIT concluded in 1987 in Manila among the six ASEAN member states, three of which may be regarded as Islamic states (Indonesia, Malaysia and Brunei). The 1980 Amman

agreed". See also n. 100.

116 The clause in Korea-Indonesia says in effect: compensation including interest shall amount to the market value, while the intention is no doubt that compensation shall amount to the market value and interest shall be payable in addition. The language used in Korea-Spain leaves it to the debtor-state to determine what (if any) interest it will pay, by saying: compensation shall include payment of interest in accordance with the laws and regulations of the expropriating state. See also $\mathrm{n} .30$ above.

${ }^{117}$ E.g., Bangladesh-US (1986) and Bangladesh-Italy (1990) have an interest clause. So has Egypt-Italy (1989), while Egypt-US (1982) contains what might be described as a crypto-interest clause: “. . . compensation shall include payment for delay as may be considered appropriate under international law”. Morocco-US (1985) makes no mention of interest in the expropriation article of the treaty, but adds in a protocol a crypto-clause to the effect that "compensation shall include as appropriate an amount to compensate for any delay in payment that may occur". The same crypto-clause (except for the words "as appropriate" has been added in a protocol attached to Tunisia-US (1990).

${ }^{118}$ Algeria, Bahrain, Indonesia, Kuwait, Malaysia, United Arab Emirates and Yemen. Some of these have occasionally concluded BITs without an interest clause, but only with countries which normally omit these clauses. See for instance Kuwait-Pakistan (1983), Malaysia-Norway (1984), Yemen-Sweden (1983). The clause in Germany-Kuwait (1994) is interesting in that it seeks to explain and justify payment of interest at considerable length: "In the event that the payment of compensation is delayed, such compensation shall be paid in an amount which would put the investor in a position not less favourable than the position in which he would have been had the compensation been paid immediately on the date of expropriation. To achieve this goal the compensation shall include interest at the prevailing commercial rate, however in no event less than the current LIBOR rate ...".

119 The 18 signatories include three of the Asian states on which our sample of 62 BITs is based, viz. Indonesia, Malaysia and Pakistan. 
treaty contains an interest clause, ${ }^{120}$ but the Baghdad and Manila treaties do not.

The three BITs of our sample which may have been affected by Islamic policies on interest are: Bangladesh-Italy, Malaysia-Denmark and ChinaPakistan. The first two have an interest clause, the last one has not, all as one would expect in the light of the treaty practice of the countries concerned as illustrated above.

\subsection{Effectiveness}

Compensation must be effective, says the HULL formula. But what does this mean? It covers two things: convertibility and transferability. ${ }^{121}$ There is hardly a compensation clause which does not deal with it, one way or another, but it is pretty clear that the authors of these various clauses attach different meanings to the terms they use.

The OECD Convention requires compensation to be "transferable to the extent necessary to make it effective for the national entitled thereto". According to the accompanying notes and comments effective means that compensation must be paid "in a form that is of real practical use to the person entitled thereto, having regard to his particular situation". So if the investor is a resident of the expropriating country it may be that non-transferable compensation is effective for him. But usually it will have to be transferable. "A transfer through the market . . . would represent a proper discharge of the obligations . . . provided it did not entail an undue reduction in the genuine value".

AALCC Model A has the HULL formula which calls for effective compensation and furthermore asks that compensation be allowed to be repatriated. Convertibility is presumably deemed to be included in effectiveness. Model B alternative 1 merely says that the state will honour commitments made in

\footnotetext{
${ }^{120}$ Art. 11.2 reads: "Compensation must be paid within one year from the date of accord on the amount of compensation or the date . . .. Otherwise the investor shall be entitled to deferment interests on the unpaid amount from the day following expiry of the said period, on the basis of the prevailing bank interest rate in the State where investment was made."

${ }^{121}$ Convertibility gives the right to convert the currency in which compensation is paid (usually the local currency) to a suitable foreign currency (usually the investor's home country's currency or an internationally freely convertible currency such as US dollars). Transferability gives the right to repatriate (i.e. transfer to the home country) the amount in foreign currency representing the compensation.
} 
regard to (inter alia) "the mode and manner of payment" of compensation. Alternative 2 is silent on the issue.

The most up to date and businesslike instruction is, one would expect, to be found in the World Bank Guidelines: compensation must be effective and this is the case if it is paid:

(a) "in the currency brought in by the investor where it remains convertible",

(b) "in another currency designated as freely usable by the IMF", or

(c) "in any other currency accepted by the investor".

However, the words which have been emphasized are unclear and the right of the investor to transfer the money abroad (the right to repatriate) after having converted it is not clearly expressed. ${ }^{122}$

Our sample of sixty-two BITs uses, apart from the HULL formula, a miscellany of expressions, including: payment in convertible currency (20x); compensation shall be convertible (or freely convertible) (14x); in freely usable currency $(2 \mathrm{x}){ }^{123}$ (freely) transferable $(49 \mathrm{x})$; allowed to be repatriated $(4 \mathrm{x})$; in the currency of the country of origin $(1 \mathrm{x})$. Thus thirty-six BITs specifically deal with convertibility and 54 with transferability. In addition, the expressions 'effectively (or fully) realizable' ( $31 \mathrm{x})$ and 'effective' $(5 \mathrm{x})$ are used without a clear meaning, presumably as a kind of catch-all phrase. The expression 'effectively realizable' was used in a number of early US Friendship, Commerce and Navigation treaties, probably to cover both convertibility and transferability. ${ }^{124}$

Most of the treaties which are silent on convertibility while dealing specifically with transferability contain one of the two last-mentioned clauses and it is a fair assumption that the states involved considered convertibility to be covered by 'realizable' or 'effective'. And reversely, BITs with a convert-

\footnotetext{
${ }^{122}$ By way of example, a US investor in Japan who originally had brought in dollars and who now gets compensation in yen, is entitled to convert the yen into dollars. But will he be allowed under these Guidelines to transfer the dollars to the US? And, if originally he had brought in the money in yen (bought in New York or, perhaps, already in his possession from other transactions), will he then not be entitled to repatriate them? What is the meaning of the words "where it remains convertible"? Does it mean that the dollars, as long as they remain in the investor's hands, may be converted back to yen? Or does it mean that an investor from a country with a currency designated by the IMF as not freely usable, having brought in this currency for an investment in Japan and after expropriation having been compensated in the same nonconvertible currency, may now convert it into a freely convertible currency?

${ }^{123}$ Korea-Zaire and Mongolia-US. The latter has added: as defined in Article 30 of the Articles of Agreement of the IMF.

${ }^{124}$ E.g. Art 6.4 of the US-Netherlands Treaty on Friendship, Commerce and Navigation of 1956: “. . . compensation shall be in an effectively realizable form".
} 
ibility clause but without one on transferability seem to have used 'realizable' or 'effective' to cover transferability.

In a world with fast-changing exchange rates an investor who is guaranteed convertibility has an interest in a realistic definition of the rate of exchange that will be applied. However, only nine BITs of our sample make an attempt to provide a definition. Sri Lanka-US prescribes the prevailing market rate on the date of expropriation, ${ }^{125}$ thus protecting US investors against a subsequent fall of Sri Lankan currency versus the dollar (but a change of the exchange rate might go the other way!). Mongolia-US, on the other hand, refers to the prevailing rate on the date of transfer ${ }^{126}$ with respect to spot transactions. Mongolia-Denmark adds, interestingly, that in the absence of a market rate the most recent exchange rate applied to inward investments will be used. Japan-Turkey uses a formula we have encountered earlier: ${ }^{127} \mathrm{com}$ pensation must be paid in a manner which would place the claimant in a position no less favourable than the position in which he would have been if the compensation had been paid immediately on the date of the expropriation.

Some BITs ${ }^{128}$ and also the World Bank Guidelines leave a significant hiatus in the guarantee of convertibility and transferability by allowing, in the words of the Guidelines, exceptions in cases where the state faces exceptional circumstances, as reflected in an arrangement for the use of the resources of the IMF or under similar objective circumstances of established foreign exchange stringencies. Compensation in foreign currency may then be paid in instalments over a period which must be as short as possible and which may not exceed five years.

\footnotetext{
${ }^{125}$ China-Greece prescribes the rate of exchange applicable on the date used for the determination of value, which normally will be the date of expropriation. China's BITs with Korea and Argentina use almost the same language.

${ }^{126}$ Same in the Vietnam BITs with Italy and Denmark.

${ }^{127}$ See $\mathrm{n} .118$ above. A similar formula is used in China-Greece for the calculation of the amount of compensation, see the 7 th example given at the end of sec. 8.2 above.

${ }^{128}$ E.g. Japan-Turkey: the host country may, in exceptional financial or economic circumstances, impose exchange restrictions in conformity with the IMF Articles of Agreement as long as it is a party to those Articles of Agreement. This wording is ambiguous. It probably should be interpreted as meaning that exchange restrictions may only be imposed by a country which is party to the IMF Articles, but it could also mean that such restrictions may always be imposed but must conform to the Articles while the country is a party to them.
} 


\section{PROTECTION OF SHAREHOLDERS}

Sixteen in our sixty-two BITs sample contain a separate clause of British origin designed to indemnify the investor's shareholders in the home country when the investment is expropriated in the host country. An interesting question is whether such a clause serves a useful purpose and, if so, why the other forty-seven BITs forego the clause. The answer depends in part on the definitions of an investor and an investment. Let us take, by way of example, the relevant clause in the Hong Kong-Australia BIT:

"Where a Contracting Party expropriates the assets of a company which is incorporated or constituted under the law in force in any part of its area, and in which investors of the other Contracting Party own shares, it shall ensure that the provisions of paragraph (1) of this Article are applied to the extent necessary to guarantee compensation referred to in paragraph (1) in respect of their investment to such investors of the other Contracting Party who are owners of those shares"

or, paraphrased (as applied to an investment in Australia):

"Where Australia expropriates the assets ${ }^{129}$ of an Australian company in which Hong Kong investors own shares, Australia must ensure that those shareholders are compensated to the extent necessary in accordance with the compensation rules above."

There are various possibilities. If the investment is made by an Australian subsidiary of a Hong Kong company, the clause would seem to be unnecessary, even confusing, because that company, which is the shareholder, is already entitled to compensation under the preceding clause which guarantees compensation to Hong Kong investors who are deprived of their investments ${ }^{130}$ in Australia.

\footnotetext{
${ }^{129}$ The definite article is significant: this clause applies only when 'the assets', i.e. all assets are expropriated, not in case of a partial expropriation.

${ }^{130}$ An investment is defined in the BIT as every kind of asset owned or controlled by the foreign (here: Hong Kong) company. The term 'control' is defined in such a way that a company which has a substantial interest in the investment is regarded as the controlling company. Under the main expropriation clause the Hong Kong parent company is therefore protected (against expropriation) as the investor, not as the shareholder. This is so both in the case that the Australian company itself, i.e. the shares therein (which constitute an asset of the parent company), is expropriated and in the case that the assets of the Australian company are expropriated. If there are noncontrolling shareholders in Hong Kong, they could base a cause of action against Australia on the separate clause for the protection of shareholders.
} 
If the investment is made by an Australian company which is jointly controlled by foreign companies in Hong Kong and other countries, each for a minority percentage, the Hong Kong company may not be regarded as having a substantial interest and on that ground being in control of the assets expropriated in Australia. The clause for protecting it as a shareholder then is its only safeguard.

The same is true for Hong Kong individuals who own a portfolio investment in the expropriated Australian company and who, thanks to the shareholder protection clause, can claim compensation "to the extent necessary", which may mean to the extent that they have not received their proportional part of the compensation paid to the expropriated company. ${ }^{131}$ Most BITs are concerned with direct investments only and do not protect the interests of foreign portfolio investors.

If the Australian company is a subsidiary of a Hong Kong company which itself is wholly owned by (for instance) a UK company, the provisions of the shareholder protection clause apply. But if a Hong Kong company wholly owned by Hong Kong shareholders makes the investment in Australia via a subsidiary in a third country (which has not a similar BIT with Australia), the shareholders protection clause does not apply. No doubt one can think of other cases where the clause would apply or would not apply and where in the light of the purpose of the BIT, namely to encourage direct investments in Australia, it should or should not apply. In the light of this analysis the standard clause appears to overshoot its mark. It could have been drafted narrower, so as to apply only where additional protection is purposeful and functional and where competing claims are avoided. Everything said in the preceding paragraphs is, of course, equally relevant to Australian investments in Hong Kong and the position of Australian parent companies and shareholders.

The shareholder protection clauses in most of the sixteen BITs under review are substantially equal to the above paradigm. In two treaties ${ }^{132}$ the restriction "to the extent necessary" has been deleted. One of the BITs ${ }^{133}$ has omitted, perhaps by inadvertence, the requirement to pay compensation to the shareholders, merely requiring that the provisions of the preceding paragraph are applied to the extent necessary in respect of the shareholders. But do the shareholders themselves have a cause of action? The clause is clearly

\footnotetext{
131 If the level of compensation paid by Australia to its domestic company is less than the standard of compensation set out in the main expropriation clause of the BIT, the Hong Kong shareholders may be entitled to the difference.

132 China-Korea and Korea-Mongolia. None of the other Chinese BITs contains a similar formula, while four Korean BITs (out of eleven) have it.

${ }^{133}$ Malaysia-Denmark.
} 
controversial and, apart from British BITs which as a rule include it, ${ }^{134}$ it is unclear why some countries accept it in some BITs and not in others. ${ }^{135}$

\section{DISPUTE SETTLEMENT AND DUE PROCESS OF LAW}

As we saw above, the expropriation clause of many BITs contains a provision requiring due process of law, sometimes as a condition precedent for lawful expropriation and sometimes as a right of the expropriated investor. According to the comment on Article 3 of the OECD Convention, due process covers two things: the measures must be lawful, in accordance with domestic legal procedures; and it must be possible to test them in court. ${ }^{136}$ Twenty BITs in our sample refer to due process of law in general, a further eight use other terms for testing the legality of the expropriation and the amount of compensation in court, such as the right of the investor to prompt review, by a judicial or other independent authority of the expropriating state, of the investor's case and of the valuation of the investment. ${ }^{137}$

Apart from such clauses, which are part of the expropriation article, virtually all BITs ${ }^{138}$ have a separate arbitration article providing for com-

\footnotetext{
134 There are some variations; the clause in Turkey-UK (1991) is interesting, as it eliminates some of the doubts caused by the standard formula. It provides that each country must ensure that in case of expropriation of investments of a company incorporated or constituted under its law and in which an investor of the other owns shares, its law provides either (i) for that company to be compensated in accordance with the provisions of the preceding paragraph; or (ii) for the investor of the other country to be compensated directly in accordance with those provisions; in no event shall this paragraph be construed so as to require a country's law to provide for both (i) and (ii). ${ }^{135}$ All five Hong Kong BITs include the clause, as well as four Korean, three Mongolian, two Thai, two Indonesian and one each of China, Vietnam, Malaysia and Nepal.

${ }^{136}$ According to the OECD comment the term implies that, whenever a state seizes property, the measures taken must be free from arbitrariness; safeguards existing in law and precedent must be fully observed; administrative or judicial machinery used or available must correspond at least to the minimum standard required by international law. Thus the term contains both substantive and procedural elements. Still following the OECD Convention, one safeguard deserves special mention: the legality of the measures taken by the expropriating state and - wherever the constitutional rules of the state concerned permit it - the amount of compensation should be subject to judicial review.

${ }^{137}$ Hong Kong-Netherlands.

${ }^{138}$ There is one exception in our sample, Korea-Zaire, which provides for arbitration of disputes between the two states but not those between the investor and the host state. See for other exceptions PETERS (1991) 119-120.
} 
pulsory ${ }^{139}$ international arbitration of disputes between the investor and the host country. Admittedly, most of the Chinese BITs (and some others) confine the scope of compulsory arbitration to a narrow range of disputes, but these always include disputes on the amount of compensation, sometimes other aspects of expropriation as well. ${ }^{140}$

Thus two strains of thought - on due process and dispute settlement come together here. Both are given for the protection of the investor, but it is doubtful whether due process, in the sense of the right to prompt judicial review in the host country of the legality of the expropriation and the amount of compensation, adds anything to the investor's security. On the contrary, it suggests the need to exhaust local remedies before a dispute may be submitted for final settlement to the arbitral tribunal. ${ }^{141}$ On the merits and demerits of the local remedies rule in international law when there is a right to arbitration there is much to say. ${ }^{142}$ The present author holds the view that, whenever there is a right to arbitration, it is in the best interest of both parties to set aside the local remedies rule. Most BITs reduce the period available for negotiation or judicial review to a few months, after which period the parties are entitled to go to international arbitration (there can be no question then of exhausting local remedies). In some BITs the local remedies rule is explicitly set aside, in our sample only in Korea-Austria.

The right of the investor to submit disputes with the host country to arbitration is an essential part of the protection ${ }^{143}$ for which BITs were made. It is disconcerting, therefore, to find that in some BITs this right is rather shaky. In Japan-Turkey the right of the investor to go to arbitration is jeopardized in two ways: it exists only as long as both Contracting Parties are

\footnotetext{
${ }^{139}$ Compulsory in the sense that either party to the dispute (or, in some BITs, only the investor) is entitled to submit a dispute to arbitration and once set in motion the procedure is compulsory for both parties.

${ }^{140}$ See Peters (1991) 129.

${ }^{141}$ This suggestion is reinforced by the wording in some BITs which, by using a 'shall'-clause, make it appear that the judicial review is a mandatory procedure, instead of being an option open to the investor.

142 See PeTERS (1991) 133-135 and SCHRIUVER (1995) 347-350.

${ }^{143}$ If the host country unilaterally changes the agreed terms of the investment, e.g. by changing laws or regulations, the local courts are likely to apply the new municipal law rather than rules or principles of international law. This applies to many countries, including the US. Cf. Restatement of the Law, Third, The Foreign Relations Law of the United States §115: “An act of Congress supersedes an earlier rule of international law or a provision of an international agreement as law of the United States if the purpose of the act to supersede . . is clear . ..". See also PETERS (1992) 231. An international arbitral tribunal is unlikely to find that municipal law takes precedence over international law.
} 
parties to the 1965 ICSID Convention, ${ }^{144}$ and the host country can make the right inoperative simply by renouncing the ICSID Convention. ${ }^{145}$ In the second place the right to arbitration of a dispute ends once the investor has resorted to administrative or judicial settlement of that dispute in the host country. If the host country insists on local remedies the way to arbitration therefore remains closed. A similar problem exists in Korea-Turkey. The investor has a right to arbitration only if he has submitted the dispute to the national courts of the host country and there has not been rendered a final award within one year after the dispute had arisen. In practice it would seem most unlikely that a final award in highest instance can be given within that period, but if it is and turns out to be a travesty of justice, it is highly unsatisfactory that the way to arbitration remains blocked. ${ }^{146}$ According to Korea-Romania, a dispute, if not settled within 6 months, "shall by agreement of parties to the dispute . . ." be submitted to ICSID. This can hardly be considered a firm right to arbitration. One last example of a deficient arbitration clause is China-Argentina where, as a result of a drafting error in the definitions, the right to arbitration turns out to apply only in case of straightforward expropriations, but not in case of a creeping nationalization. ${ }^{147}$

A review of the three examples with which we have compared the BITs all along, yields no surprises. The OECD Convention merely requires that the measures are taken "under due process of law". It does not provide for

\footnotetext{
144 The Convention on the Settlement of Investment Disputes between States and Nationals of other States, Washington, 1965.

145 The Thai BITs with Korea, Czechoslovakia and Peru also require both Contracting Parties to be party to ICSID in order that the investor's right to arbitration can be implemented. There is a simple expedient used in many other BITs (e.g. most recent British BITs) to avoid this, namely by giving the investor (or the parties to the dispute) a choice between several forms of arbitration, including a non-administered system such as UNCITRAL arbitration, so that the right to arbitration will not be dependent on the host country.

${ }^{146}$ The same problem is posed by China-Pakistan.

${ }^{147}$ Art. 4 uses the following words: "any measure of nationalization or expropriation (hereafter referred to as 'expropriation') or any other measure having similar effect ..."; and for all such measures compensation is due. Art. 8 provides for international arbitration for disputes arising about investments in China in the case of a dispute "involving the amount of compensation for expropriation". Clearly, this arbitration is not applicable for measures "having similar effect", so-called creeping nationalization. As the English text prevails over the Chinese and Spanish texts, this error - assuming this result was not intended - could have unpleasant consequences for the investor.
} 
arbitration between the host country and the investor. ${ }^{148}$ The expropriation article of AALCC Model A provides that "the determination of the compensation, in the absence of agreement . . ., shall be referred to an independent judicial or administrative tribunal or authority ... or to arbitration . . .". Model B, Article 9, gives the investor right of access to courts and tribunals of the host country for review of expropriation measures. It requires local remedies to be exhausted prior to any other proceedings. The World Bank Guidelines require that expropriation measures are "in accordance with applicable legal procedures" and goes on to state that disputes, failing settlement through negotiation, "will normally be settled . . . through national courts or through other agreed mechanisms including . . . binding independent arbitration". Binding independent arbitration is not, therefore, according to the Guidelines, a conditio sine qua non. The absence of a firm right to arbitration is a regrettable hiatus in the protective armour provided by the Guidelines. Perhaps it was inevitable for the World Bank Group to be restrained by the terms of its own ICSID: the preamble of the ICSID Convention declares that member states are never, without their consent, bound to submit a dispute to arbitration (except only that, according to Article 25 of the Convention, a party having given its consent may not withdraw it unilaterally).

\section{CONCLUDING REMARKS}

At the end of this detailed review, having considered all the main elements of the expropriation clauses we found in the sixty-two treaties of our sample, several conclusions can be drawn.

The essential rule on expropriation in virtually all BITs is the same:

(i) the host state is entitled under certain circumstances to expropriate foreign investments;

(ii) it must pay compensation;

(iii) if there is a dispute about compensation, it can be submitted to independent arbitration.

The small print on matters such as conditionality, detailed methods of valuation, and convertibility and transferability of funds shows significant differences, and provisions in some BITs are unsatisfactory, but these are not

\footnotetext{
${ }^{148}$ Many of the early BITs, in particular the German, Swiss and Chinese ones, made no provision for direct arbitration between investors and host country. In case of a dispute that could not be resolved by negotiations between the parties to the dispute, the investor had to rely on his home country to concern itself with his interests and seek a solution, if necessary, through intergovernmental arbitration. Cf. PETERS (1991) 119.
} 
the most essential elements on which security of investment depends. The most essential element is a clause which safeguards the integrity of contracts made between the investor and the government of the host country, i.e. a pacta sunt servanda clause which purports to elevate an undertaking made by the host country vis-à-vis the investor to the level of international law, by converting it into an undertaking vis-à-vis the home country. Such a clause ensures that an investor can himself make the necessary arrangements with the host country on valuation, convertibility, transferability and anything else he deems important, and that he can be confident that such arrangements will stick, that they cannot be abrogated unilaterally by the host country on the strength of its sovereign powers.

We briefly touched on this subject in section 5.5 above, in the context of a clause requiring compliance with specific undertakings given by the host country. In view of the importance of the concept, both as a cornerstone of investment protection and as a newly emerging and still controversial principle of international law, some further clarification may be useful here.

The controversial aspect is, of course, the implication that companies should be treated as subjects of international law. The concept of a functional international legal personality for non-state entities (other than intergovernmental organizations, whose international legal personality is not in doubt), however limited it may be, still is difficult to accept for many states. Nevertheless, it has been accepted so far in at least two contexts: ICSID and UNCLOS. The ICSID Convention of 1965 , now signed by more than 130 countries, was created especially for the purpose of allowing disputes between a state and a foreign investor to be settled by international arbitration. It made room for the investor in the house of international law, but only if the state in question wanted it. Clearly, this formula has been successful, as evidenced by the large number of states which participate in ICSID. Admittance to international law through ICSID is restricted to foreign investors or, in other words, to Transnational Corporations (TNCs) in UN parlance, or Multinational Enterprises (MNEs), according to OECD terminology. ${ }^{149}$

In Article 153(2)(b) of the 1982 UN Convention on the Law of the Sea, room was made for "juridical persons which possess the nationality of States

\footnotetext{
${ }^{149}$ In practice a foreign investor is, almost by definition, a TNC or MNC or, more precisely, a company belonging to an international group of companies known as a TNC or MNC. Not all TNCs (MNEs), however, are necessarily foreign investors. Some may restrict their foreign activities to trade or other things, such as banking, and abstain from investing. The terms TNC and MNE are misleading, they suggest for a group of companies a single legal personality which does not exist. A TNC is not a corporation, but a group of corporations. An MNC need not be multinational but may be restricted to establishments in two or three countries.
} 
Parties or are effectively controlled by them or their nationals, when sponsored by such States". Such juridical persons (companies) can enter into contracts with the International Seabed Authority for conducting deep seabed mining operations and under such contracts they will have rights and obligations governed by the Convention. Thus they will be subjects of international law. Disputes arising in this context may be submitted to the dispute settlement machinery specified in Articles 187 and 188 of the Convention, with one interesting exception which reveals the misgivings which existed when these provisions were negotiated: according to Article 190(2) a respondent state cannot be forced to appear in an action brought by a company. It may ask the sponsoring state to appear in lieu of the company, or it may arrange to be represented itself by a company of its own nationality. The message is clear: it is unseemly for a sovereign state and a mere company to appear in court as equals.

However, the procedures developed in order to 'elevate' an undertaking made by the host country vis-a-vis the investor to the level of international law, by 'converting' it into an undertaking vis-à-vis the home country, do not violate this taboo. Let us be precise. There is a contract between State A (the host state) and the investing company $\mathrm{C}$ (or its parent company). The 'undertakings' (i.e. obligations) assumed by A under that contract are subject to the law of the contract, which may be the law of State A, or it may be A's law together with the rules of international law, or it may have been defined in some other way; but it is unlikely to be international law as such. There is also a treaty (BIT) between A and C's home State B, according to which A must carry out the undertakings (i.e. obligations) which it has assumed vis-a-vis $C$. What does this mean? It does not constitute a novatio in the sense of Roman civil law. The novatio is a legal institution, in Roman law and in many legal systems derived from Roman law, whereby one obligation is substituted by another: in our case, if A's obligation to $\mathrm{C}$ were substituted by another obligation by $\mathrm{A}$ to $\mathrm{B}$, with the concomitant extinction of A's obligation to $\mathrm{C}$, it would have been a novatio. But this is not what has happened. The effect of the BIT clause is that a new obligation is created, an obligation by A to B, which does not extinguish the obligation by $A$ to $C$. The A-to-B obligation is subject to international law. The A-to-C obligation is, in all likelihood, subject to another law, the law of the contract between $\mathrm{A}$ and $\mathrm{C}$. Moreover, $\mathrm{C}$ cannot force $\mathrm{B}$ to enforce the A-to-B obligation. This is entirely at the discretion of $\mathrm{B}$ (there is a parallel here with B's right to give diplomatic protection to $\mathrm{C}$ against $\mathrm{A}$; this, too, is a matter for B's discretion and is not a right which $\mathrm{C}$ 
can invoke against B). ${ }^{150} \mathrm{~B}$ can hold $\mathrm{A}$ to its obligation under the BIT, even if $C$ does not want it. It is clear that B's claim against $A$ is not the same as C's claim against $A$, even if the substantive content of A's obligation is the same in both cases.

One striking difference between the two legal claims is the applicable law. It is true that different applicable laws may be indicated in a contract or in a treaty to deal with different aspects of parties' relations or with different legal questions (so-called dépeçage, as recognized in the 1980 EC Convention of Rome on contractual obligations, which allows the parties to select the law applicable to the whole or a part only of the contract). However, we are here faced with two separate obligations (A-to-B and A-to-C) and the concept of dépeçage strictly does not apply. Neither is there merit in the argument that the dépeçage doctrine should be applied by analogy in this case, where there are two separate obligations with the same content. For in practice dépeçage often causes more problems than it solves, and it is therefore little used. ${ }^{151}$

Investors generally do not want to be dependent on their home government for the implementation of their legal rights against the host country. Home governments are often reluctant to take up the cudgels for their TNCs in foreign investment disputes. Pacta sunt servanda clauses in BITs which the home government may - or may not - invoke, will not solve all problems and will not satisfy or reassure all investors. Nevertheless, coupled with international arbitration, ${ }^{152}$ they give a powerful boost to investors' confidence in the stability of investment terms and thus to the promotion of investment. Hence their importance.

Coming back now to the variations and discrepancies we noted in BIT texts, there are at least two good reasons why it would be desirable to eliminate all these small, relatively unimportant differences of detail between

${ }^{150} \mathrm{Cf}$. the legal position between A, B and C when A seeks to enforce a CALvo clause against C. $B$ is entitled under international law to extend its diplomatic protection to $C$ against $A$ and may require A to desist from its claim against $\mathrm{C}$. But $\mathrm{B}$ is not obliged to do so. Under international law $C$ is not entitled to diplomatic protection from B, even though (hypothetically) it may be so entitled under B's own law (however, few if any states give a right to diplomatic protection to their citizens). $\mathrm{B}$ may take action against $\mathrm{A}$ if it considers it to be in its own national interest, even if $\mathrm{C}$ does not want it. It is clear that $\mathrm{B}$ has a right of its own and does not merely represent $C$ in the defence of C's legal rights. See SHEA (1955) and SCHRIJVR (1995) 166.

151 See Peters (1992) at 236 n. 9, and PolaK (1994) 25.

152 A national court of the host country may find that the government's undertaking given to the investor was ultra vires or has been overridden by subsequent legislation. It is unlikely then to find in favour of the investor on the ground that he is entitled to direct application of the BIT clause. An international arbitral tribunal, on the other hand, is more likely to give priority to international law (including provisions of the BIT) over rules of municipal law which frustrate the object and purpose of the treaty. 
one BIT and another. There is the purely practical question of treaty-making convenience: if roughly 150 states want to regulate mutual investment matters bilaterally, it takes about 11,000 treaties to achieve total coverage. About 1,300 treaty links already exist by virtue of some 900 BITs and 5 MITs so far concluded, or will exist once they have all entered into force, leaving 9,800 new bilateral treaties to be concluded. The man-power and time required for such a job and its cost make bilateral coverage unattractive. It could be done more efficiently by means of one global Multilateral Investment Treaty, or by a small number of regional ones such as the ASEAN MIT of 1987.

As perceived by capital exporting countries, the principal objection to the global approach has long been the danger of compromise solutions, thereby sacrificing important matters of principle. It seems to me, however, that the process of cross-fertilization between BITs in the last ten years and the dwindling of the more extreme NIEO and CERDS-based doctrines have by now reduced this danger so far that the advantages of a global solution now far exceed the disadvantages. The global approach of the Havana Charter of 1948, abandoned shortly thereafter, and again in the draft OECD Convention of 1967, also abandoned, should be tried once more.

The second reason is more important. A comparison of BITs shows that there is a virtual consensus between them on most of the important questions, even though there are differences of detail, as pointed out in this paper. These minor differences still stand in the way of the emergence of a body of customary law on investment. If they were eliminated by the adoption of a uniform set of rules and principles in a new global treaty or investment code, it would not be long before they, or most of them, would be recognized as customary international law which could be invoked also against (and by) states which were not party to that treaty.

We have reviewed in this paper the rules adopted by states to regulate expropriation of foreign investments. The rationale of these rules is to encourage foreign investment by reducing the risks attached to it. Protection of investments is a means to achieve the true purpose of the BITs: to promote investment. It is sometimes argued that the need for BITs is disappearing fast, firstly because the overriding priorities of environmental protection, in particular the dangers of climate change, require a reduction of industrial investment rather than its encouragement; and secondly because the danger of expropriation is a station we have passed, a policy of the days of cold war and command economies, no longer relevant at a time of world-wide privatization.

This seems a short-sighted view. While it is likely, and indeed desirable, that the rate of new industrial investment world-wide should slow down considerably in order to achieve the objectives of the 1992 Climate Change Convention and other environmental priorities, this will affect industrialized 
countries more than developing ones, and industrial investment more than investment in infrastructure and services. There will still be a lot of investment in the future, most of all in restructuring industry so as to become 'sustainable'. As far as expropriation or other government measures with equivalent effect are concerned, it is true that in the last ten years there has been a sharp reduction in the use made by governments of this instrument of social and economic policy. But trends in government behaviour, whether towards liberal or planned economies, internationalist or isolationist policies, centralized or decentralized organization structures, and an infinite number of others, have always been unpredictable and often cyclical. We should use the present period of relative stability and non-confrontational relations between governments and industry, to create a solid international treaty system for the regulation of investment matters for the 21 st century.

\section{LITERATURE}

DALY (1991): HERMAN DALY, Steady-state economics (Washington DC, 1991).

DOlzer and SteVens (1995): RUdolf Dolzer and MARGRete STEVens, Bilateral investment treaties (Martinus Nijhoff Publ., 1995).

LILLICH (1972): R.B. LILLICH (ed.), Valuation of Nationalised Property (1972).

Meadows et al. (1972): D.H. MEadows, D.L. Meadows, J. Randers and W. BEHRENS III, The limits to growth (London, 1972).

Meadows et al. (1991): D.H. MEAdows, D.L. MEAdows and J. RANDERS, Beyond the limits (Earthscan Publ., London, 1991).

PETERS (1988): PAUL PETERS, 'Investment risk and trust: the role of international law', in: DE WAART, PETERS and DENTERS (eds.), International Law and Development (Martinus Nijhoff Publ., Dordrecht, 1988).

PeTERS (1991): PAUL PETERS, 'Dispute settlement arrangements in investment treaties', in: 22 NYIL (1991) 91-161.

Peters (1992): PAUL PETERS, 'The semantics of applicable law clauses and the arbitrator', in: M. SumAMPouw et al. (eds.) Law and Reality, Essays on National and International Procedural Law in honour of C.C.A. Voskuil (Martinus Nijhoff Publ., 1992).

PETERS (1995): PAUL PETERS, 'Sustainable development and good governance: the transition to a steady-state economy', in: GINTHER, DENTERS and DE WAART (eds.), Sustainable Development and Good Governance (Martinus Nijhoff Publ., Dordrecht, 1995). 
POLAK (1994): MAURICE V. POLAK, Dépeçage, een rechtsbegrip dat in het ipr misstaat? (dépeçage, a legal notion unbecoming in private international law?) (Kluwer, 1994).

SCHACHTER (1984): O. SCHACHTER, 'Compensation for Expropriation', 78 AJIL (1984) 121-130.

SCHRIJVER (1995): NICO SCHRIJVER, Sovereignty over natural resources: balancing rights and duties in an interdependent world (1995).

SHEA (1955): D.R. SHEA, The Calvo Clause: a problem of Inter-American and international law and diplomacy (University of Minnesota Press, Minneapolis, 1955).

SORNARAJAH (1994): M. SORNARAJAH, The international law on foreign investment (Grotius Publ., CUP, Cambridge, 1994).

SORNARAJAH (1995): M. SoRNARAJAH, 'Protection of foreign investments in the AsiaPacific Economic Co-operation Region', 29 Journal of World Trade (1995) 105-129. 


\section{BILATERAL INVESTMENT TREATIES}

concluded or ratified by countries in South, East and South-East Asia since January 1, 1990 (according to information available as of 15.03.96)

This list contains 114 such treaties. ${ }^{153}$ The 62 which were included in the sample used for the analyses described in this paper are marked $*$. The date of signature and the date of entry into force of each BIT is given below. The symbol nif [not in force] indicates that the treaty had not yet entered into force on the date stated. The source of treaty texts is given whenever available, either by reference to the national treaty series where the text has been published (see the list of abbreviations below), or by reference to Investment Promotion and Protection Treaties as compiled by ICSID and published by Oceana Publications Inc. (London, Rome and New York; indicated below by the symbol OP [Oceana Publications]). The text or publication details of some BITs - marked 'na' - are not yet available to the author and in some cases they appear not to have been published. Treaties listed twice are marked ' + '.

\begin{tabular}{|c|c|c|c|}
\hline \multicolumn{4}{|c|}{ 2010 } \\
\hline BANGLADES & & & \\
\hline Turkey & 12.11 .87 & 21.06 .90 & na \\
\hline *Italy & 20.03 .90 & $20.09 .94 ?$ & GU(so) 31.08.93; GU(so) 25.07.95; OP \\
\hline Netherlands & 01.11 .94 & nif 01.05 .96 & Trb 1995:10 \\
\hline
\end{tabular}

$\begin{array}{llll}\text { CHINA } & & & \\ \text { Malaysia }+ & 21.11 .88 & 31.03 .90 & \text { na } \\ \text { *Pakistan }+ & 12.02 .89 & 30.09 .90 & \text { OP } \\ \text { Bulgaria } & 27.06 .89 & 21.08 .94 & \text { OP } \\ \text { USSR } & & 21.07 .90 & \text { nif } 15.05 .95 \mathrm{na} \\ \text { Turkey } & 13.11 .90 & 19.08 .94 & \text { na } \\ \text { Papua New Guinea } & & 12.04 .91 & 12.02 .93 \mathrm{na} \\ \text { Hungary } & 29.05 .91 & 01.04 .93 & \text { na } \\ \text { *Mongolia } & 26.08 .91 & 01.11 .93 & \text { OP } \\ \text { Czechoslovakia } & 04.12 .91 & 01.12 .92 & \text { OP } \\ \text { *Portugal } & 03.02 .92 & 01.12 .92 & \text { Diario da Rep. 23.07.92 } \\ \text { *Spain } & & 06.02 .92 & \text { 01.05.93BOE } 04.10 .93 / 20.01 .94 \\ \text { Uzbekistan } & 13.03 .92 & 14.04 .94 & \text { na } \\ \text { Bolivia } & 08.05 .92 & \text { nif } 15.05 .95 & \text { na } \\ \text { Kyrgyzstan } & 14.05 .92 & \text { nif } 15.05 .95 & \text { na } \\ \text { *Greece } & 25.06 .92 & 21.12 .93 & \text { na } \\ \text { Armenia } & 04.07 .92 & \text { nif } 15.05 .95 & \text { na } \\ \text { *Philippines }+ & 20.07 .92 & \text { nif } 15.05 .95 & \text { OP } \\ \text { Kazakhstan } & 10.08 .92 & 13.08 .94 & \text { na } \\ \text { *Korea }+ & 30.09 .92 & 04.12 .92 & \text { na } \\ \text { Ukraine } & 31.10 .92 & 29.05 .93 & \text { na }\end{array}$

${ }^{153}$ One BIT (Korea-Thailand) was included in the list and in the sample for analysis, notwithstanding the fact that, marginally, it falls outside the date definition. 


\begin{tabular}{llll} 
*Argentina & 05.11 .92 & 01.08 .94 & OP \\
Moldova & 07.11 .92 & 01.03 .95 & na \\
Turkmenistan & 21.11 .92 & 06.06 .95 & na \\
*Vietnam+ & 02.12 .92 & 01.09 .93 & OP \\
Belarus & 11.01 .93 & 14.01 .95 & na \\
*Laos + & 31.01 .93 & 01.06 .93 & OP \\
*Albania & 13.02 .93 & nif 15.05 .95 & OP \\
Tajikistan & 09.03 .93 & 20.01 .94 & na \\
*Georgia & 03.06 .93 & 01.03 .95 & OP \\
*Croatia & 07.06 .93 & 01.07 .94 & OP \\
UAE & 01.07 .93 & 28.09 .94 & na \\
*Estonia & 02.09 .93 & 01.06 .94 & OP \\
*Slovenia & 13.09 .93 & 01.01 .95 & OP \\
Lithuania & 08.11 .93 & 01.06 .94 & OP \\
*Uruguay & 02.12 .93 & nif 15.05 .95 & OP \\
Azerbaijan & 08.03 .94 & 01.04 .95 & na \\
Ecuador & 21.03 .94 & nif 15.05 .95 & OP \\
Chile & 23.03 .94 & nif 15.05 .95 & OP \\
Iceland & 31.03 .94 & nif 15.05 .95 & na \\
Egypt & 21.04 .94 & nif 15.05 .95 & na \\
Peru & 09.06 .94 & 01.02 .95 & na \\
Romania & 12.07 .94 & nif 15.05 .95 & na \\
Jamaica & 26.10 .94 & nif 15.05 .95 & na \\
Indonesia + & 18.11 .94 & 01.04 .95 & na \\
Oman & & 18.03 .95 & nif $15.05 .95 n a$ \\
Morocco & 27.03 .95 & nif 15.05 .95 & na \\
Israel & 10.04 .95 & nif 15.05 .95 & na \\
Cuba & 24.04 .95 & nif 15.05 .95 & na \\
\hline & & &
\end{tabular}

\section{HONG KONG}

*Netherlands

$19.11 .92 \quad 01.09 .93$

Trb 1993:10 \& 109; OP

*Australia

15.09 .93

15.10 .93

ATS 1993 30; OP

*Denmark

02.02 .94

04.03.94

27.05 .94

26.06 .94

Lovtidende C 1995:30

*Sweden

*Switzerland

22.09 .94

22.10 .94

na

31.01 .96

nif 04.06.96

na

na

INDIA

United Kingdom

Germany

14.03.94 06.01 .95

TS27(1995) Cm 2797

10.07.95

nif 04.06 .96

na

Netherlands

06.11 .95

nif 01.05 .96

Trb 1995:286

INDONESIA

Singapore+

*Korea +

$28.08 .90 \quad 28.08 .90$

GG(ts)31.08.90 [re: Riau Island]

16.02.91

10.03.94

OP

*Italy

$25.04 .91 \quad 24.06 .95$

GU(so) 31.12.94 


\begin{tabular}{|c|c|c|c|}
\hline & signed & in force & source \\
\hline Vietnam + & 25.10 .91 & 03.12 .93 & na \\
\hline *Norway & 26.11 .91 & 01.10 .94 & OmFS 1995 p. 336; OP \\
\hline Hungary & 20.05 .92 & 12.09 .92 & na \\
\hline Sweden & 17.09 .92 & 18.02 .93 & na \\
\hline Poland & 06.10 .92 & 01.07 .93 & na \\
\hline *Australia & 17.11 .92 & 29.07 .93 & ATS 1993 19; OP \\
\hline Egypt & 19.01.94 & nif 01.04 .94 & na \\
\hline Malaysia + & 22.01 .94 & nif 01.04 .94 & na \\
\hline *Netherlands & 06.04 .94 & 01.07 .95 & Trb 94: $109 \& 238$ \\
\hline China + & 18.11 .94 & 01.04 .95 & na \\
\hline Spain & 30.05 .95 & nif 31.05 .96 & na \\
\hline \multicolumn{4}{|l|}{ JAPAN } \\
\hline *Turkey & 12.02 .92 & 12.03 .93 & 37 JAIL (1994) p.189 \\
\hline \multicolumn{4}{|l|}{ KOREA } \\
\hline Pakistan + & 24.05 .88 & 15.04 .90 & na \\
\hline *Italy & 10.01 .89 & 25.06 .92 & GU(so) 23.01.92; OP \\
\hline *Thailand & 24.03 .89 & 30.09 .89 & $\mathrm{OP}^{154}$ \\
\hline *Poland & 01.11 .89 & 02.02 .90 & OP \\
\hline *Zaire & 19.07 .90 & & OP \\
\hline *Romania & 07.08 .90 & & OP \\
\hline *USSR & 14.12 .90 & 10.07 .91 & OP \\
\hline *Indonesia + & 16.02 .91 & 10.03 .94 & OP \\
\hline *Austria & 14.03 .91 & 01.11 .91 & BGB 03.10 .91 p.2205; OP \\
\hline *Mongolia + & 28.03 .91 & 30.04 .91 & $\mathrm{OP}$ \\
\hline *Turkey & 14.05 .91 & & OP \\
\hline${ }^{*}$ China + & 30.09 .92 & 04.12 .92 & na \\
\hline Peru & 03.06 .93 & & OP \\
\hline Lithuania & 24.09 .93 & & OP \\
\hline *Spain & 17.01 .94 & 19.07.94 & BOE 13.12 .94 p. 37487 \\
\hline Argentina & 17.05 .94 & nif 01.06 .95 & na \\
\hline \multicolumn{4}{|l|}{ LAOS } \\
\hline *France & 12.12 .89 & 08.03 .91 & JO 1991 p.5793; OP \\
\hline Thailand + & 22.08 .90 & & na \\
\hline *China + & 31.01 .93 & 01.06 .93 & OP \\
\hline *Australia & 06.04 .94 & 08.04 .95 & $\mathrm{OP}$ \\
\hline \multicolumn{4}{|l|}{ MALAYSIA } \\
\hline Italy & 04.01 .88 & 25.10 .90 & GU(so) 02.05 .90 \\
\hline China + & 21.11 .88 & 31.03 .90 & na \\
\hline *Denmark & 06.01 .92 & 18.09 .92 & Lovtidende C 1993:128; OP \\
\hline
\end{tabular}

${ }^{154}$ See note 153. 


$\begin{array}{llll} & \text { signed } & \text { in force } & \text { source } \\ \text { Chile } & 11.11 .92 & & \text { OP } \\ \text { Poland } & 21.04 .93 & 27.03 .94 & \text { na } \\ \text { Indonesia }+ & 22.01 .94 & \text { nif } 01.04 .94 & \text { na } \\ \text { Zimbabwe } & 28.04 .94 & & \text { na } \\ \text { Argentina } & 06.09 .94 & \text { nif } 01.06 .95 & \text { na } \\ \text { Spain } & 04.04 .95 & 16.02 .96 & \text { BOE 08.03.96 }\end{array}$

MONGOLIA

*Korea +

*Germany

*China +

*United Kingdom

*France

BLEU

*Italy

*United States

Netherlands

28.03.91

26.06 .91

30.04 .91

OP

26.08.91

nif 04.06 .96

BGB 1996 II p. 50

04.10 .91

01.11 .93

OP

08.11 .91

04.10 .91

TS22 (1992) Cm 1959; OP

22.12 .93

03.03 .92

nif 29.03 .93

JO 1994 p. 4469

15.01 .93

nif 01.05 .95

na

06.10 .94

nif 01.06 .96

GU(so) 27.12.94

09.03 .95

nif 01.06 .96

Senate Treaty doc. 104-10

*Denmark

13.03 .95

nif 07.06.95 na

NEPAL

*United Kingdom

$02.03 .93 \quad 02.03 .93$

TS55 (1993) Cm 2327; OP

PAKISTAN

Korea +

Netherlands

24.05 .88

15.04 .90

na

04.10 .88

01.10 .89

Trb 1988:149; OP

*China +

Spain

12.02 .89

30.09 .90

15.09 .94

nif 26.04 .96

OP

30.11 .94

30.11 .94

na

United Kingdom

08.03.95

04.05 .95

TS24 (1995) Cm 2794

GG(ts) 13.04.95

PAPUA NEW GUINEA

*Australia

China +

PHILIPPINES

Italy

*China +

*Spain

France

*Australia

SINGAPORE

Indonesia +

Vietnam +
03.09.90

12.04 .91

20.10 .91

12.02 .93

ATS 1991 38; OP

na
17.06.88 04.11.93 GU(so) 12.07.90; amended in GU 58, 11.03.94

20.07.92 nif 15.05.95 OP

$19.10 .93 \quad 21.09 .94$

BOE 17.11.94 p. 35272; BOE 05.10.95

p. 29253

13.09.94 nif 09.05.95 na

$25.01 .95 \quad 08.12 .95 \quad$ ATS 199528

$28.08 .90 \quad 28.08 .90$

$29.10 .92 \quad 25.12 .92$
GG(ts)31.08.90 [re: Riau Island]

GG(ts) 06.11 .92 


$\begin{array}{llll} & \text { signed } & \text { in force } & \text { source } \\ \text { Poland } & 03.06 .93 & 29.12 .93 & \text { GG(ts) } 10.12 .93 \\ \text { Pakistan+ } & 08.03 .95 & 04.05 .95 & \text { GG(ts) } 13.04 .95 \\ \text { Czech Rep. } & 08.04 .95 & \text { nif } 26.04 .95 & \text { na } \\ & & & \\ \text { SRI LANKA } & & & \\ \text { *United States } & 20.09 .91 & 01.05 .93 & \text { OP; Senate Treaty doc. 102-25 } \\ & & & \\ \text { THAILAND } & & & \\ \text { *Korea } & 24.03 .89 & 30.09 .89 & \text { OP } 155 \\ \text { Laos + } & 22.08 .90 & & \text { na } \\ \text { *Czechoslovakia } & 16.10 .91 & & \text { OP } \\ \text { Hungary } & 18.10 .91 & & \text { na } \\ \text { Vietnam+ } & 30.10 .91 & & \text { na } \\ \text { *Peru } & 15.11 .91 & 15.11 .91 & \text { OP } \\ \text { Poland } & 18.12 .92 & 10.08 .93 & \text { na } \\ \text { Czech Rep. } & 12.02 .94 & & \text { na } \\ & & & \\ \text { VIETNAM } & & & \\ \text { *Italy } & 18.05 .90 & \text { nif } 01.05 .95 & \text { GU(so) 26.03.94; OP } \\ \text { *Australia } & 05.03 .91 & 11.09 .91 & \text { ATS 1991 36; 30 ILM 1064 (1991); OP } \\ \text { BLEU } & 24.01 .91 & \text { nif } 29.03 .93 & \text { na } \\ \text { Indonesia+ } & 25.10 .91 & 03.12 .93 & \text { na } \\ \text { Thailand+ } & 30.10 .91 & & \text { na } \\ \text { *France } & 26.05 .92 & 10.08 .94 & \text { JO 1994 p. 16222 } \\ \text { *Switzerland } & 03.07 .92 & 03.12 .92 & \text { OP } \\ \text { Singapore+ } & 29.10 .92 & 25.12 .92 & \text { GG(ts) 06.11.92 } \\ \text { *China+ } & 02.12 .92 & 01.09 .93 & \text { OP } \\ \text { *Germany } & 03.04 .93 & \text { nif } 04.06 .96 & \text { na } \\ \text { *Denmark } & 25.08 .93 & 07.08 .94 & \text { Lovtidende C 1995:28 } \\ \text { *Sweden } & 08.09 .93 & 02.08 .94 & \text { na } \\ \text { *Netherlands } & 10.03 .94 & 01.02 .95 & \text { Trb 94:82 } \\ \text { Poland } & 31.08 .94 & \text { nif } 26.05 .95 & \text { na } \\ & & & \end{array}$

\section{ABBREVIATIONS}

$\begin{array}{ll}\text { ATS } & =\text { Australian Treaty Series } \\ \text { BGB } & =\text { (Austrian) Bundesgesetzblatt } \\ \text { BLEU } & =\text { Belgo-Luxemburg Economic Union } \\ \text { BOE } & =\text { Boletin Oficial de España } \\ \text { Diario da Rep. } & =\text { (Portuguese) Diario da República } \\ \text { GG(ts) } & =\text { (Singapore) Government Gazette (treaty series) }\end{array}$

${ }^{155}$ See note 153. 


$\begin{array}{ll}\text { GU(so) } & =\text { (Italian) Gazzetta Ufficiale, supplemento ordinario } \\ \text { ILM } & =\text { International Legal Materials } \\ \text { JAIL } & \text { Japanese Annual of International Law } \\ \text { JO } & \text { (French) Journal Officiel } \\ \text { Lovtidende C } & =\text { (Danish) Lovtidende Part C (official treaty series) } \\ \text { OmFS } & =\text { Overenskomster med Fremmede Stater (Norwegian treaty series) } \\ \text { OP } & =\text { Investment Promotion and Protection Treaties compiled by ICSID } \\ & \text { and published by Oceana Publications, Inc. (London, Rome and } \\ & \text { New York) } \\ \text { Trb } & =\text { (Dutch) Tractatenblad (treaty series) } \\ \text { TS (1995) Cm }= & \text { Treaty Series (1995) (of the UK) with command paper number } \\ \text { UAE } & =\text { United Arab Emirates } \\ \text { USSR } & =\text { Union of Socialist Soviet Republics }\end{array}$

